\title{
16. CHEMISTRY OF PRIMARY AND SECONDARY PHASES IN INTRAPLATE BASALTS AND VOLCANICLASTIC SEDIMENTS, DEEP SEA DRILLING PROJECT LEG $89^{1}$
}

\author{
P. A. Floyd and G. Rowbotham, Department of Geology, University of Keele ${ }^{2}$
}

\begin{abstract}
Electron microprobe data are presented for clinopyroxenes, plagioclases, palagonites, smectites, celadonites, and zeolites in Hole $462 \mathrm{~A}$ sheet-flow basalts and Site 585 volcaniclastic sediments. Glomerocrystic clinopyroxenes in Hole $462 \mathrm{~A}$ are predominantly $\mathrm{Ti}$-poor augites with minor fractionation to ferroaugites in rim portions. Quenched plumose clinopyroxenes show considerable variation from $\mathrm{Ca}$-rich to $\mathrm{Ca}$-poor augites, although all are characterized by being $\mathrm{Ti}$ rich and $\mathrm{Cr}$-poor relative to the glomerocrysts. Two differentiated series of Site 585 pyroxene compositions, calcic augite and diopside-salite, demonstrate the coexistence, in the vitric and lithic clasts, of tholeiitic and alkali basalt types, respectively. Plagioclase compositions in all samples are mainly labradorites, although some zoned Hole $462 \mathrm{~A}$ glomerocrysts range from $\mathrm{An}_{73}$ to $\mathrm{An}_{20}$ and are characterized by high $\mathrm{Mg}$ and $\mathrm{Fe}$ contents in the more calcic varieties. The $\mathrm{K}$ content of the plagioclases is highest in the more sodic crystals, although the overall higher orthoclase component of Site 585 plagioclases reflects the generally higher bulk-rock $\mathrm{K}$ content.

The compositions of both secondary smectites and celadonites are similar irrespective of the alteration location (glass, matrix, vesicles, etc.), although brown smectites replacing interstitial glass have marginally higher total Fe contents than pale green and yellow smectites. Analyzed zeolites are mainly phillipsites with variable alkali content, and, together with associated celadonite, represent late-stage alteration repositories for $\mathrm{K}$ under mildly oxidizing conditions. The compositions of both early and late secondary minerals are typical of those formed by the submarine alteration of basaltic rocks at low temperatures.
\end{abstract}

\section{INTRODUCTION}

The basalt sheet-flows of Hole $462 \mathrm{~A}$ and the reworked hyaloclastites of Site 585 are representative of two different expressions of mid-Cretaceous intraplate volcanism (Fig. 1). The sheet-flows cover extensive areas of the west and central Pacific Ocean (Winterer, 1973), and are the products of fissure eruptions through thermally domed Jurassic ocean floor (Larson and Schlanger, 1981; Schlanger and Premoli Silva, 1981). The sheet-flow basalts have incompatible-element-depleted compositions similar to those of mid-ocean ridge basalts (MORB), but differ significantly in some aspects of this chemistry (Batiza et al., 1980; Saunders, this volume; Floyd, this volume). Cretaceous volcaniclastic sediments are also abundant throughout basinal deeps of the western $\mathrm{Pa}$ cific, and represent mass-flow accumulations of hyaloclastite debris derived from the flanks of adjacent seamounts. Petrographically and chemically, the component vitric and lithic clasts are similar to ocean island basalts, and probably represent the late edifice-building stage of seamount evolution (Kelts and Arthur, 1981). Although both alkalic and tholeiitic basalts are present among the clast types, incompatible-element-enriched basalts, similar to Hawaiian tholeiites, are dominant in some volcaniclastic units (Floyd, this volume).

Taking into account the different tectonic settings and variation in petrographic and chemical features of the intraplate basalts sampled during Leg 89 , primary phases were analyzed by electron microprobe to determine

\footnotetext{
${ }^{1}$ Moberly, R., Schlanger, S. O., et al., Init. Repts. DSDP, 89: Washington (U.S. Govt. Printing Office).

2 Address: Dept. of Geology, University of Keele, Staffordshire, U.K. ST5 5BG.
}

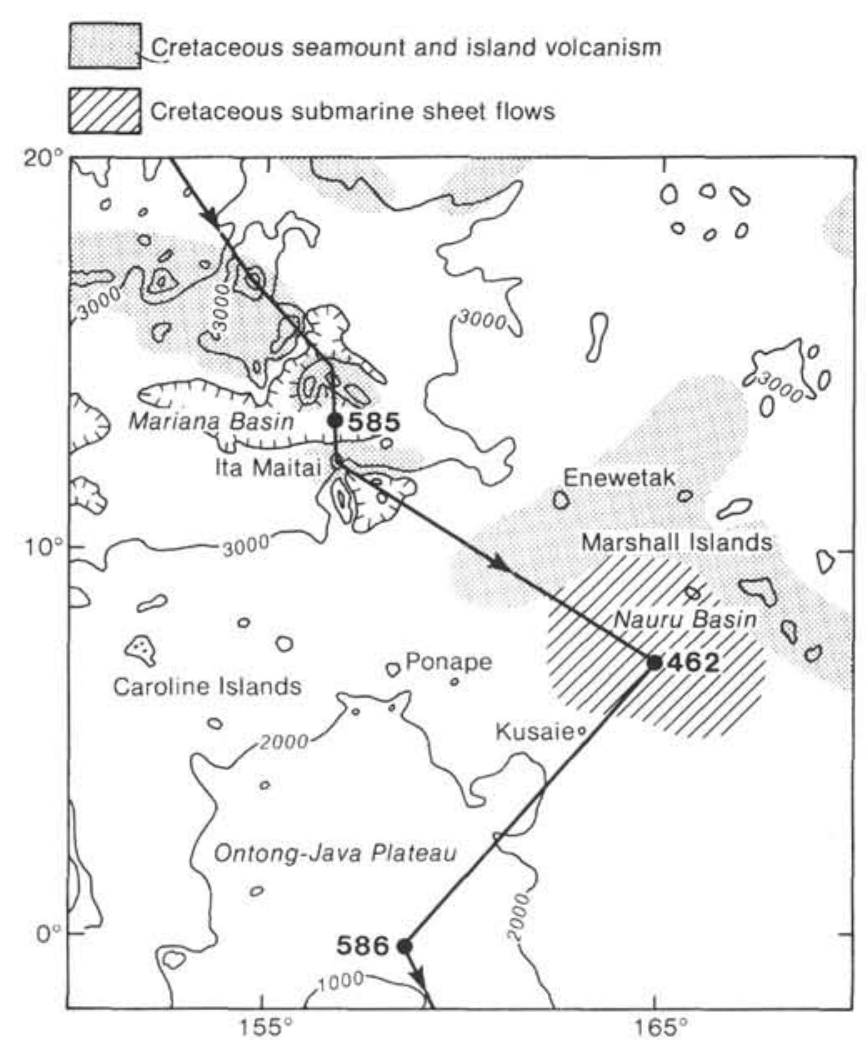

Figure 1. Map of the southwest Pacific showing positions of Sites 585 and 462. (Bathymetry in meters.)

their respective compositional variations relative to bulk rock composition and petrogenesis, and to compare them with typical mid-ocean ridge basalts (MORB) and ocean island basalts (OIB). Probe analysis of glass shards and 
fresh clinopyroxene clasts and phenocrysts in volcaniclastic sediments is particularly useful to determine magma type and degree of fractionation in otherwise altered polymictic debris.

Both the Hole $462 \mathrm{~A}$ sheet-flows and the Site 585 volcaniclastic sediments underwent low-grade submarine anoxic alteration involving the development of palagonite, smectites, celadonites, and zeolites. Some of these secondary phases were also analyzed to determine changes with replacement under low-grade conditions.

\section{ANALYTICAL METHODS}

Mineral analyses were obtained using a Cameca (Camebax) electron microprobe at the University of Manchester, Department of Geology. The operating conditions were $15 \mathrm{kV}$ and $3.5 \times 10^{-8} \mathrm{~A}$ and a spot size of $\sim 3 \mu \mathrm{m}$, except in the analysis of hydrous phases, when the beam was defocused. The calibration is against metals, oxides, and silicates. An estimate of the accuracy and precision of this technique is reported by Dunham and Wilkinson (1978).

\section{PETROGRAPHY OF SAMPLES}

The Leg 89 samples, within which a variety of primary (clinopyroxene, plagioclase) and secondary (palagonite, smectite, celadonite) phases were analyzed, are listed in Table 1, together with characteristic features.
The Hole 462A sheet-flows are plagioclase-clinopyroxene \pm olivine phyric and aphyric basalts that invariably contain interstitial glass. Plagioclase and clinopyroxene phenocrysts may be anhedral or subhedral, and frequently occur in glomerocrystic groups. The matrix of rapidly chilled quench-textured basalts is composed of dark plumose clinopyroxene spherulites and variolites, small plagioclase laths or forked microlites, and minute magnetite granules, often set in glass. In coarsergrained aphyric basalts, plagioclase forms elongate crystals with serrated edges that may be associated together in bowties. Matrix clinopyroxene may form open feathery plumes or granular masses, some of the larger crystals of which may subophitically enclose plagioclase bowties. Magnetite granules and dendrites are nearly always developed in interstitial glass, although in the holocrystalline basalts magnetite has an intersertal relationship to earlier clinopyroxene and plagioclase. Crystallization sequence of primary phases in rapidly quenched glassy basalts is olivine (rare), plagioclase, clinopyroxene, magnetite, and, in coarser-grained varieties, glomerocrystic plagioclase + clinopyroxene, matrix plagioclase + clinopyroxene, clinopyroxene, and magnetite. Fresh interstitial glass is rare throughout Hole $462 \mathrm{~A}$ basalts and is

Table 1. Locations and petrographic features of analyzed Leg 89 samples.

\begin{tabular}{|c|c|c|c|c|}
\hline $\begin{array}{c}\text { Keele } \\
\text { number }\end{array}$ & $\begin{array}{l}\text { DSDP Sample } \\
\text { (interval in } \mathrm{cm} \text { ) }\end{array}$ & $\begin{array}{l}\text { Volcanic } \\
\text { unit }^{\mathrm{a}}\end{array}$ & Lithology & Petrographic features \\
\hline $585-35$ & $585-48-1,141-144$ & 4 & Lithic-vitric tuff & $\begin{array}{l}\text { Alteration-zoned green palagonite shards with } \\
\text { plagioclase and clinopyroxene phenocrysts; } \\
\text { few plagioclase phyric lithics. }\end{array}$ \\
\hline $585-41$ & $585-51, C C, 17-21$ & 5 & Lithic-vitric tuff & $\begin{array}{l}\text { Alteration-zoned yellow to brown vesicular } \\
\text { palagonite shards; few lithics; much } \\
\text { smectite matrix. }\end{array}$ \\
\hline $585-46$ & $585-54-2,58-62$ & 5 & $\begin{array}{l}\text { Crystal-lithic } \\
\text { lapillistone }\end{array}$ & $\begin{array}{l}\text { Clinopyroxene megacrysts; lithics mainly } \\
\text { microphyric glassy basalts and tachylite } \\
\text { with clinopyroxene and plagioclase pheno- } \\
\text { crysts. }\end{array}$ \\
\hline $585 \mathrm{~A}-7$ & $585 A-13-5,13-17$ & 5 & $\begin{array}{l}\text { Crystal-lithic-vitric } \\
\text { tuff }\end{array}$ & $\begin{array}{l}\text { Palagonite- and smectite-replaced glass with } \\
\text { zoned smectite infilling vesicles; tachylite; } \\
\text { plagioclase megacrysts partly replaced by } \\
\text { green smectite or celadonite. }\end{array}$ \\
\hline $585 \mathrm{~A}-23$ & $585 A-20-2,121-123$ & 6 & $\begin{array}{l}\text { Tholeiitic basalt } \\
\text { clast }\end{array}$ & $\begin{array}{l}\text { Fine-grained sparsely plagioclase phyric } \\
\text { holocrystalline basalt; zoned vesicle infill- } \\
\text { ings. }\end{array}$ \\
\hline $585 A-26$ & $585 \mathrm{~A}-21-1,61-65$ & 6 & Alkali basalt clast & $\begin{array}{l}\text { Nonvesicular aphyric medium-grained holo- } \\
\text { crystalline basalt; fibrous green and brown } \\
\text { smectite in matrix. }\end{array}$ \\
\hline $585 \mathrm{~A}-31$ & $585 \mathrm{~A}-22-2,10-14$ & 6 & Lithic-vitric tuff & $\begin{array}{l}\text { Golden brown palagonite clasts with plagio- } \\
\text { clase micro-and mega-phenocrysts; minor } \\
\text { quenched lithic; fine-grained smectitic } \\
\text { matrix. }\end{array}$ \\
\hline $462 \mathrm{~A}-17$ & $462 A-96-2,122-127$ & 46 & $\begin{array}{l}\text { Plagioclase- } \\
\text { clinopyroxene } \\
\text { phyric basalt }\end{array}$ & $\begin{array}{l}\text { Moderately clinopyroxene-plagioclase glomero- } \\
\text { phyric hypocrystalline basalt; interstitial } \\
\text { glass replaced by brownish smectite. }\end{array}$ \\
\hline $462 \mathrm{~A}-32$ & $462 \mathrm{~A}-101-5,52-56$ & 48 & Aphyric basalt & $\begin{array}{l}\text { Medium-grained hypocrystalline basalt; skeletal } \\
\text { plagioclase; plagioclase alteration domains } \\
\text { with zeolite, K-feldspar and smectite. }\end{array}$ \\
\hline $462 \mathrm{~A}-55$ & $462 A-105-1,52-56$ & 52 & $\begin{array}{l}\text { Plagioclase- } \\
\text { clinopyroxene } \\
\text { phyric basalt }\end{array}$ & $\begin{array}{l}\text { Sparsely plagioclase-clinopyroxene phyric } \\
\text { hypocrystalline basalt; quench-textured } \\
\text { with plumose clinopyroxene variolites. }\end{array}$ \\
\hline $462 \mathrm{~A}-57$ & $462 A-105-2,58-63$ & 52 & Aphyric basalt & $\begin{array}{l}\text { Coarse-grained hypocrystalline basalt; elongate } \\
\text { skeletal plagioclase; interstitial glass } \\
\text { replaced by yellow palagonite and brown } \\
\text { smectite. }\end{array}$ \\
\hline $462 \mathrm{~A}-65$ & $462 \mathrm{~A}-108-1,17-22$ & 52 & Aphyric basalt & $\begin{array}{l}\text { Coarse-grained holocrystalline basalt; plagio- } \\
\text { clase alteration domains with zeolite and } \\
\text { K-feldspar. }\end{array}$ \\
\hline $462 \mathrm{~A}-71$ & $462 \mathrm{~A}-108-3,75-78$ & 54 & $\begin{array}{l}\text { Plagioclase- } \\
\text { clinopyroxene } \\
\text { phyric basalt }\end{array}$ & $\begin{array}{l}\text { Moderately plagioclase-clinopyroxene glomero- } \\
\text { phyric hypocrystalline basalt; interstitial } \\
\text { glass crowded with magnetite granules, } \\
\text { replaced by yellow palagonite. }\end{array}$ \\
\hline
\end{tabular}

a See Floyd (this volume). 
not present in the basalts sampled, always having been replaced by yellow palagonite and/or brown smectite. The cores of phenocrystic plagioclase may be replaced by greenish smectite. The most noticeable alteration feature of the coarse-grained, more massive basalt flows is the development of coexisting green and brown smectites, zeolites, and $\mathrm{K}$-feldspar replacing plagioclase-rich areas (plagioclase alteration domains, Table 1).

Site 585 volcaniclastic sediments are variably crystallithic-vitric tuffs, and represent reworked basaltic hyaloclastites. Although small sideromelane shards are present in the tuffs (Floyd, this volume) they were not found in the thin sections actually prepared for probe work. The majority of the vitric fragments are now yellow-brown or greenish palagonite that may show margin-contouring dark alteration zones or partial replacement by smectite. Some contain greenish smectite- or celadonite-replaced plagioclase microphenocrysts and megaphenocrysts and fresh clinopyroxene megaphenocrysts. Many of the "free-floating" clinopyroxene megacrystic fragments in the matrix have been derived by fragmentation of glass during cooling. Vesicularity of the vitric fragments varies considerably, although vesicles are invariably infilled with secondary smectite or occasionally zeolite. Some of the larger vesicles show optically continuous concentric zones of secondary minerals, ranging from different-colored smectites at the rim to a core of coarse-grained celadonite. Lithic fragments are generally plagioclasephyric tachylite containing quench crystallites, or more crystalline plagioclase- and/or clinopyroxene-phyric basalts. Plagioclase may be partly replaced by green smectite, whereas clinopyroxene is always fresh. Some basaltic clasts are vesicular, with infilling of smectite.
In summary, of the phases analyzed in the sheet-flows and sediments, both plagioclase and clinopyroxene can occur either as microphenocrysts and megaphenocrysts or in the matrix; glass is invariably represented by either replacement palagonite or smectite; and smectite \pm celadonite occur in different alteration sites such as plagioclase phenocrysts and vesicles.

\section{PRIMARY PHASES}

The two primary phases analyzed were clinopyroxene and plagioclase; representative analyses of samples from both the basalt sheet-flows and the volcaniclastic sediments are shown in Tables 2 and 3.

\section{Clinopyroxenes}

Both glomerophyric and matrix clinopyroxenes in Hole $462 \mathrm{~A}$ basalts are predominantly augites, although two variation trends are displayed (Fig. 2). The ferroaugites reflect internal fractional crystallization as these compositions are developed at the extreme rims of augite glomerocrysts. The trend from augite to subcalcic augite is representative of metastable plumose pyroxene variolites developed in rapidly quenched zones. Apart from the Ca content (Fig. 2), there are other chemical differences between the quenched and equilibrated clinopyroxenes. In terms of non-quadrilateral components, the quenched clinopyroxenes are generally richer in $\mathrm{Ti}$ and $\mathrm{Na}$, with marginally higher $\mathrm{Ti} / \mathrm{Al}$ ratios (Fig. 3 ) but lower $\mathrm{Cr}$ contents. Similarly, although both glomerocrysts and matrix clinopyroxenes are augites, they differ slightly in non-quadrilateral components, the former generally being poorer in $\mathrm{Ti}$ and $\mathrm{Al}$; the $\mathrm{Ti} / \mathrm{Al}$ ratio remains essen-

Table 2. Clinopyroxene compositions, Hole 462A (sample numbers 1-10) and Site 585 (sample numbers 11-20), Leg 89.

\begin{tabular}{|c|c|c|c|c|c|c|c|c|c|c|c|c|c|c|c|c|c|c|c|c|}
\hline & 1 & 2 & 3 & 4 & 5 & 6 & 7 & 8 & 9 & 10 & 11 & 12 & 13 & 14 & 15 & 16 & 17 & 18 & 19 & 20 \\
\hline $\mathrm{SiO}_{2}$ & 53.15 & 51.66 & 51.84 & 52.47 & 52.79 & 52.96 & 52.08 & 49.90 & 53.45 & 52.67 & 49.01 & 49.07 & 49.50 & 47.72 & 52.97 & 51.88 & 50.71 & 48.33 & 51.82 & 51.90 \\
\hline $\mathrm{TiO}_{2}$ & 0.25 & 0.54 & 0.76 & 0.25 & 0.36 & 0.30 & 0.55 & 0.71 & 0.26 & 0.33 & 1.61 & 1.75 & 1.77 & 2.57 & 0.71 & 0.87 & 1.92 & 3.25 & 1.02 & 0.83 \\
\hline $\mathrm{Al}_{2} \mathrm{O}_{3}$ & 2.05 & 2.91 & 3.57 & 2.33 & 1.70 & 2.27 & 2.70 & 1.46 & 1.55 & 1.50 & 4.95 & 4.39 & 3.16 & 4.01 & 1.73 & 2.74 & 3.36 & 5.38 & 2.45 & 2.92 \\
\hline $\mathrm{FeO}^{*}$ & 6.81 & 7.82 & 11.71 & 6.77 & 7.59 & 7.35 & 11.52 & 24.73 & 12.27 & 7.82 & 6.71 & 10.14 & 12.27 & 11.37 & 6.62 & 6.19 & 8.14 & 7.63 & 3.83 & 4.04 \\
\hline $\mathrm{MnO}$ & 0.12 & 0.16 & 0.20 & 0.06 & 0.14 & 0.14 & 0.10 & 0.60 & 0.54 & 0.29 & 0.07 & 0.16 & 0.20 & 0.24 & 0.09 & 0.07 & 0.00 & 0.26 & 0.20 & 0.07 \\
\hline $\mathrm{MgO}$ & 17.56 & 16.67 & 19.55 & $\cdot 17.28$ & 17.47 & 17.38 & 20.52 & 10.17 & 20.44 & 18.61 & 14.97 & 13.14 & 14.77 & 13.10 & 18.19 & 17.22 & 15.58 & 13.48 & 16.10 & 16.11 \\
\hline $\mathrm{CaO}$ & 20.09 & 18.74 & 11.90 & 19.94 & 19.14 & 19.70 & 11.57 & 13.40 & 11.84 & 17.45 & 21.45 & 21.57 & 16.68 & 19.68 & 18.22 & 19.92 & 20.67 & 21.77 & 23.00 & 23.59 \\
\hline $\mathrm{Na}_{2} \mathrm{O}$ & 0.17 & 0.16 & 0.29 & 0.51 & 0.25 & 0.43 & 0.21 & 0.26 & 0.43 & 0.61 & 0.43 & 0.63 & 0.85 & 0.33 & 0.50 & 0.47 & 0.37 & 0.62 & 0.13 & 0.42 \\
\hline $\mathrm{K}_{2} \mathrm{O}$ & 0.00 & 0.06 & 0.00 & 0.00 & 0.00 & 0.00 & 0.00 & 0.00 & 0.00 & 0.07 & 0.00 & 0.00 & 0.02 & 0.00 & 0.00 & 0.00 & 0.00 & 0.00 & 0.02 & 0.02 \\
\hline $\mathrm{Cr}_{2} \mathrm{O}_{3}$ & 0.47 & 0.55 & 0.09 & 0.50 & 0.38 & 0.36 & 0.21 & 0.00 & 0.00 & 0.25 & 0.93 & 0.06 & 0.23 & 0.25 & 0.73 & 1.17 & 0.00 & 0.00 & 0.77 & 1.06 \\
\hline
\end{tabular}

Cations/ 6 oxygens

$\begin{array}{lllllllllllllllllllll}\mathrm{Si} & 1.939 & 1.917 & 1.904 & 1.927 & 1.945 & 1.931 & 1.918 & 1.939 & 1.952 & 1.943 & 1.819 & 1.834 & 1.872 & 1.823 & 1.942 & 1.898 & 1.869 & 1.793 & 1.913 & 1.892 \\ \mathrm{Ti} & 0.007 & 0.015 & 0.021 & 0.007 & 0.010 & 0.008 & 0.015 & 0.021 & 0.007 & 0.009 & 0.045 & 0.049 & 0.050 & 0.074 & 0.020 & 0.024 & 0.053 & 0.091 & 0.028 & 0.023 \\ \mathrm{Al} I \mathrm{IV} & 0.061 & 0.083 & 0.096 & 0.073 & 0.055 & 0.069 & 0.082 & 0.061 & 0.048 & 0.057 & 0.181 & 0.166 & 0.128 & 0.177 & 0.058 & 0.102 & 0.131 & 0.207 & 0.087 & 0.108 \\ \mathrm{Al} \mathrm{VI} & 0.027 & 0.044 & 0.059 & 0.028 & 0.019 & 0.028 & 0.035 & 0.006 & 0.019 & 0.008 & 0.035 & 0.027 & 0.013 & 0.003 & 0.017 & 0.016 & 0.015 & 0.028 & 0.020 & 0.018 \\ \mathrm{Fe} & 0.208 & 0.243 & 0.360 & 0.208 & 0.234 & 0.224 & 0.355 & 0.804 & 0.375 & 0.241 & 0.208 & 0.317 & 0.388 & 0.363 & 0.203 & 0.189 & 0.251 & 0.237 & 0.118 & 0.123 \\ \mathrm{Mn} & 0.004 & 0.005 & 0.006 & 0.002 & 0.004 & 0.004 & 0.003 & 0.020 & 0.017 & 0.009 & 0.002 & 0.002 & 0.007 & 0.008 & 0.003 & 0.002 & 0.000 & 0.008 & 0.006 & 0.002 \\ \mathrm{Mg} & 0.954 & 0.922 & 1.070 & 0.946 & 0.960 & 0.945 & 1.127 & 0.589 & 1.113 & 1.023 & 0.828 & 0.732 & 0.832 & 0.746 & 0.993 & 0.939 & 0.856 & 0.746 & 0.886 & 0.875 \\ \mathrm{Ca} & 0.785 & 0.745 & 0.468 & 0.785 & 0.756 & 0.770 & 0.457 & 0.558 & 0.463 & 0.690 & 0.853 & 0.864 & 0.676 & 0.806 & 0.716 & 0.781 & 0.816 & 0.866 & 0.909 & 0.921 \\ \mathrm{Na} & 0.012 & 0.012 & 0.021 & 0.036 & 0.018 & 0.031 & 0.015 & 0.020 & 0.030 & 0.044 & 0.031 & 0.046 & 0.062 & 0.025 & 0.036 & 0.034 & 0.027 & 0.045 & 0.009 & 0.030 \\ \mathrm{~K} & 0.000 & 0.003 & 0.000 & 0.000 & 0.000 & 0.000 & 0.000 & 0.000 & 0.000 & 0.003 & 0.000 & 0.000 & 0.001 & 0.000 & 0.000 & 0.000 & 0.000 & 0.000 & 0.001 & 0.001 \\ \mathrm{Cr} & 0.014 & 0.016 & 0.003 & 0.014 & 0.011 & 0.010 & 0.006 & 0.000 & 0.000 & 0.007 & 0.027 & 0.002 & 0.007 & 0.001 & 0.021 & 0.034 & 0.000 & 0.000 & 0.023 & 0.031\end{array}$

Note: Sample data: Samples 1 to 4: core and rim portions of microphenocryst, variolitic plume, and glomerocryst core, respectively (462A-105-11, 52-56 cm). Samples 5, 6: core and rim portions of glomerocryst (462A-96-2, 122-127 cm). Sample 7: Plumose variolite (462A-105-2, 58-63 cm). Samples 8 to 10: extreme rim, rim, and core portions of phenocryst, respectively (462A-108-1, 17-22 cm.). Samples 11, 12: core and rim portions of a matrix pyroxene in basalt clast (585A-21-1, 61-65 cm). Samples 13, 14: core and rim portions of a matrix pyroxene in basalt clast (585A-20-2, 121-123 cm). Samples 15, 16: core and rim portions of a matrix pyroxene in basalt clast $(585-51, C \mathrm{C}, 17-21 \mathrm{~cm})$. Samples 17,18 : core and rim portions of a microphenocryst in a plagioclase phyric basalt clast (585-48-1, 141-144 cm). Samples 19, 20: core and rim portions of free-floating megacryst in lapillistone (585-54-2, 58-62 cm). 

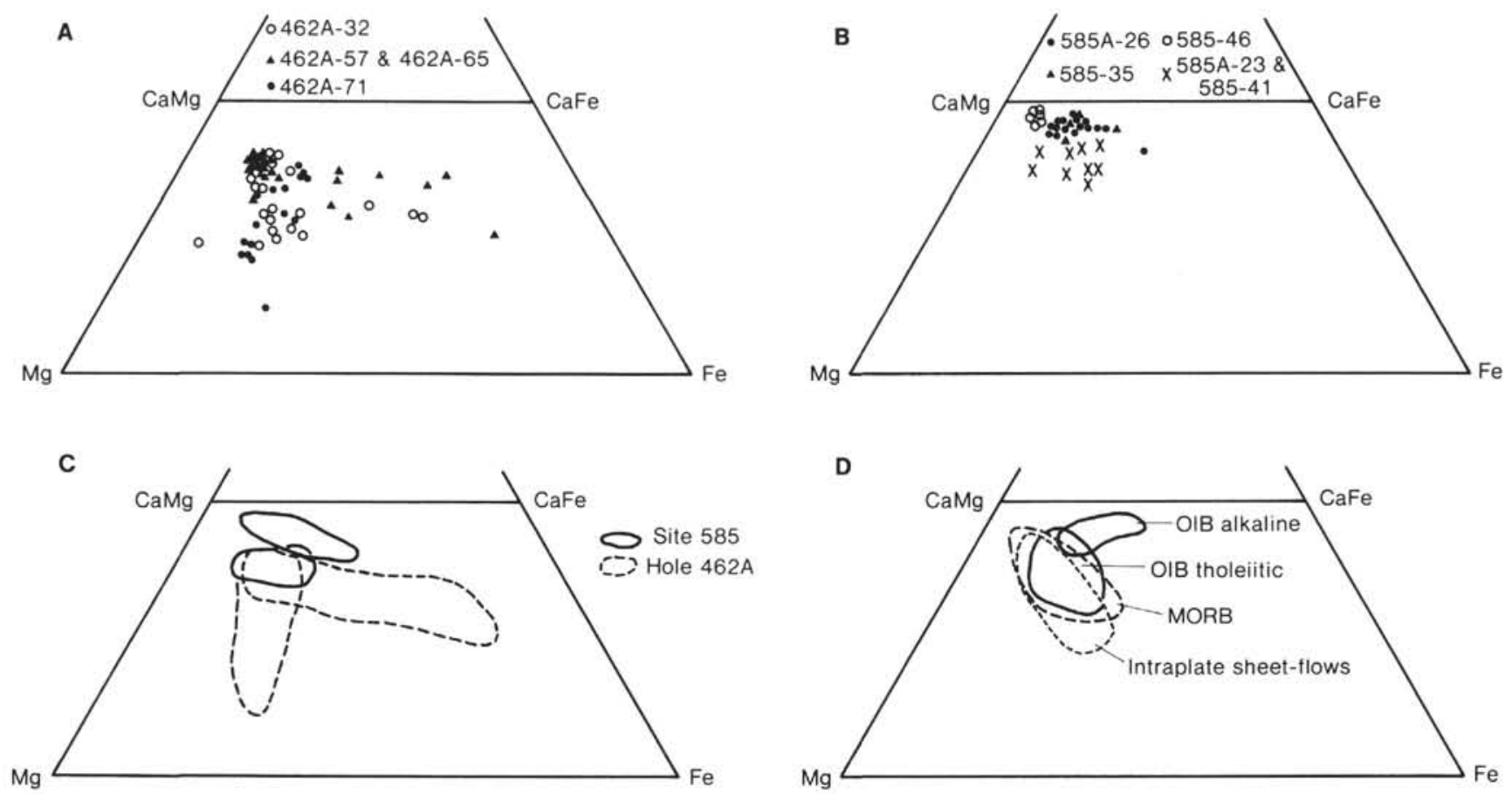

Figure 2. Pyroxene quadrilateral with data for separate Leg 89 samples. (Sample numbers shown are our Keele numbers; see Table 1 for corresponding DSDP sample numbers.) A. Hole 462A data. B. Site 585 data. C. Average trends of variation at the two locations relative to different pyroxene types. D. Comparison with clinopyroxenes from oceanic island basalts (OIB) (Hawaiian-Emperor chain; Clague et al., 1980), midocean ridge basalts (MORB) (Caribbean; Bence et al., 1975; Schweitzer et al., 1979), and intraplate sheet-flow basalts (Nauru Basin; Tokuyama and Batiza, 1981).
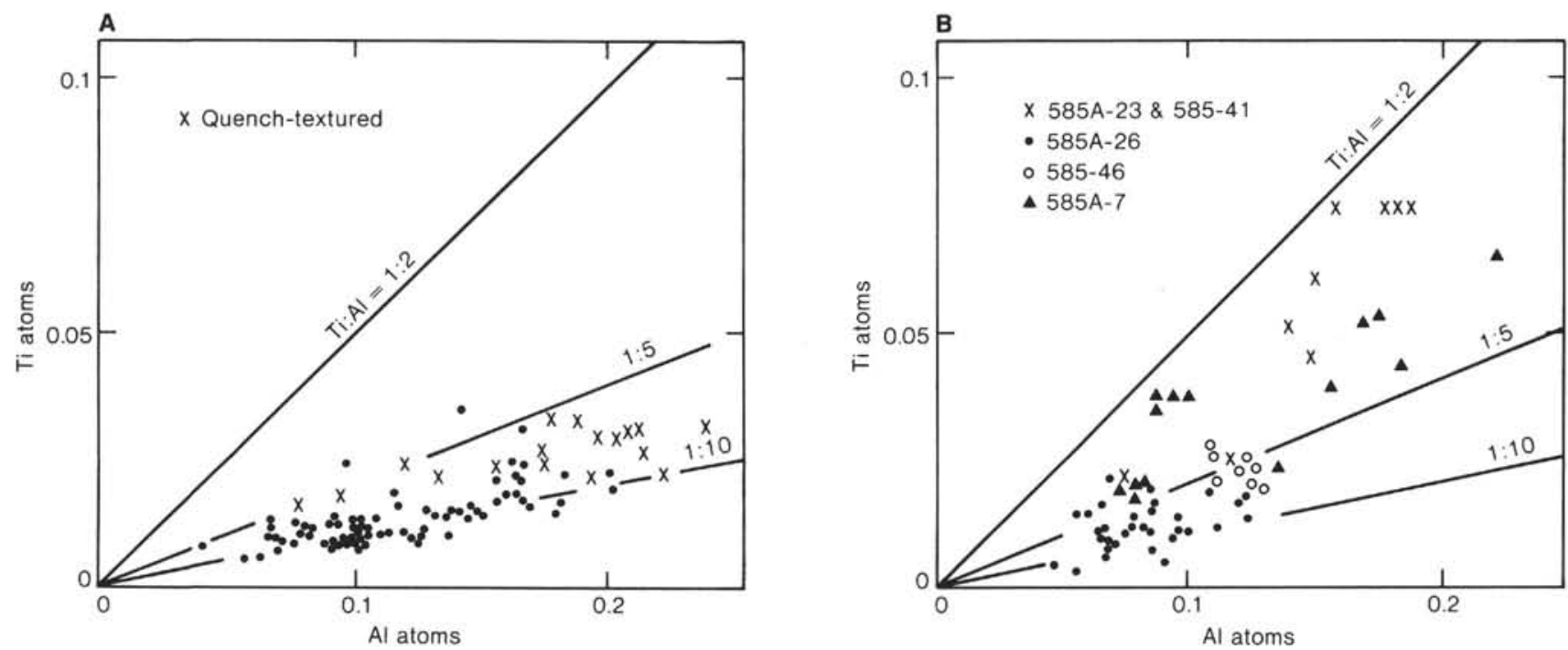

Figure 3. Plot of non-quadrilateral components $\mathrm{Ti}$ and $\mathrm{Al}$ in clinopyroxenes from (A) Hole 462A and (B) Site 585. (Sample numbers shown are our Keele numbers; see Table 1 for corresponding DSDP sample numbers.)

tially constant for both groups. Cr content is also higher in glomerocrysts, and probably reflects the absence of early crystallizing spinel in these basalts, which would otherwise accommodate most of the $\mathrm{Cr}$ available.

Hole 462A clinopyroxenes have compositions typical of those in tholeiitic magmas, which commonly have less than 45 atomic $\% \mathrm{Ca}$ in the pyroxene quadrilateral and low tetrahedral $\mathrm{Al}, \mathrm{Ti}$, and $\mathrm{Na}$ (Wilkinson, 1956; Le Bas, 1962; Coombs, 1963). As seen in Figure 4, they plot in the low-Ti portion of the tholeiitic field (Leterrier et al., 1982), and reflect the generally low Ti content of the bulk rock (average $\mathrm{TiO}_{2}=1.25 \mathrm{wt} . \%$ ). In their overall compositions and the metastable trend in the pyroxene quadrilateral, they are similar to clinopyroxenes in the lower basalt flows of Hole 462A (Leg 61), analyzed by Tokuyama and Batiza (1981). In the same way that the Nauru Basin basalts have a chemistry akin to that of MORB, the clinopyroxenes also show some simi- 


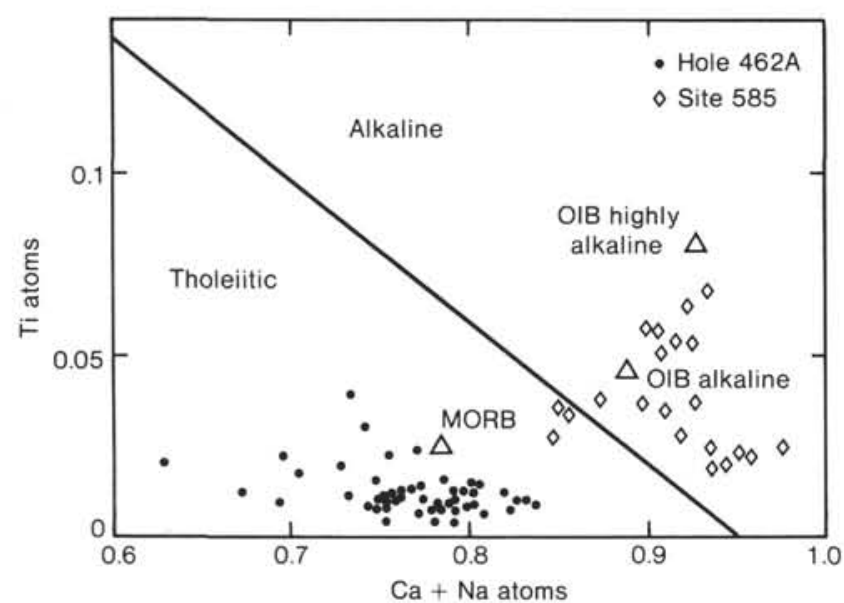

Figure 4. Magma-type discrimination of clinopyroxenes for Hole 462A glomerocrysts and Site 585 megacrysts and phenocrysts in terms of $\mathrm{Ti}$ and $\mathrm{Ca}+\mathrm{Na}$. The divide and the average MORB and OIB values are from Leterrier et al. (1982).

larities (Fig. 2), although they can be distinguished by their relative proportions of non-quadrilateral components, especially Ti (Fig. 4).

The pyroxenes analyzed in the Site 585 volcaniclastics are predominantly "free-floating" matrix megacrysts, with the exception of Samples 585A-20-2, 121-123 cm and 585A-21-1, 61-65 cm (Table 1), which are small subhedral clinopyroxenes within the matrix of basaltic clasts. Within the pyroxene quadrilateral (Fig. 2) they form two groups, one Ca-rich and composed of diopside-salitecalcic augite, the other with less $\mathrm{Ca}$ and characterized by typical augite compositions. The degree of fractionation exhibited by both groups and the actual within-sample variation are relatively limited; for example, note the tight clustering of the diopsides in Sample 585-54-2, 58-62 $\mathrm{cm}$ (Fig. 2). The pyroxenes of the calcic group are clearly "alkaline" magma pyroxenes, and can be compared to oceanic island alkali basalt clinopyroxenes (Figs. 2, 4, 5). On the other hand, the augites are more typically "tholeiitic," and in the majority of cases come from a basalt clast (585A-20-2, 101-123 cm) that has an overall tholeiitic chemical composition (Floyd, this volume). They are, however, more titaniferous than the Nauru Basin tholeiitic clinopyroxenes (Fig. 3), and reflect the characteristically Ti-rich composition of OIB relative to MORB types. Pyroxene compositions clearly demonstrate the existence of both alkaline and tholeiitic magma types, as suggested by clast petrography and chemical analysis of extracted clasts (Floyd, this volume). Also, as suggested by the spread of $\mathrm{Ti} / \mathrm{Al}$ ratios in the "alkaline magma" clinopyroxenes, a number of different alkali basalt lineages may be present that reflect bulk rock compositions. The coexistence of tholeiitic and alkaline compositions at a late stage of submarine edifice development suggests their close association well before that seen in subaerial Hawaiian volcanoes (Macdonald and Katsura, 1964).

\section{Plagioclases}

Plagioclase compositions show no systematic or significant lithologic, volcanic, or chemical groups in Hole

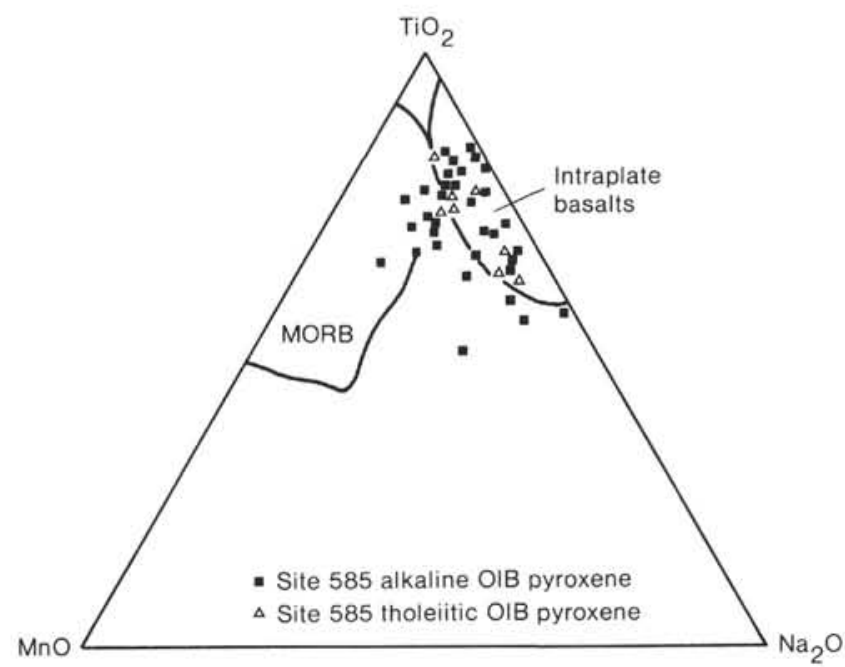

Figure 5. Distribution of intraplate Site 585 clinopyroxenes in the pyroxene tectonic discrimination diagram of Nisbet and Pearce (1977). Hole $462 \mathrm{~A}$ clinopyroxenes, with very low $\mathrm{Na}_{2} \mathrm{O}, \mathrm{TiO}_{2}$, and $\mathrm{Al}_{2} \mathrm{O}_{3}$ contents, scatter over the whole diagram and are not discriminated.

$462 \mathrm{~A}$ basalts. Plagioclase glomerocrysts are zoned with bytownite cores (on average, $\mathrm{An}_{72}$ ) and intermediate labradorite rims $\left(\mathrm{An}_{63}\right)$, although in a few cases (e.g., Sample 462A-96-2, 122-127 cm) the extreme margins of some crystals were highly albitic $\left(\mathrm{An}_{12-20}\right)$. Matrix laths, predominantly sodic labradorite (average $\mathrm{An}_{59}$ ), show less variation and contain minor $\mathrm{K}\left(\mathrm{Or}_{0.4}\right)$, whereas the bulk of the glomerocrysts have essentially none. In general, the Or end-member increases as the temperature of crystallization decreases, such that the albitic rims exhibit the highest orthoclase content, $\mathrm{Or}_{2.3}$ (Fig. 6). As in the Nauru Basin plagioclases that Tokuyama and Batiza (1981) documented, the $\mathrm{Mg}$ content decreases and $\mathrm{Fe}$ increases with falling An content in our samples also (Fig. 7). The generally low $\mathrm{Mg}$ contents (max. 0.4 wt.\% $\mathrm{MgO})$ and decreasing trend with An reflect the influence of coprecipitating clinopyroxene in both the glomero-

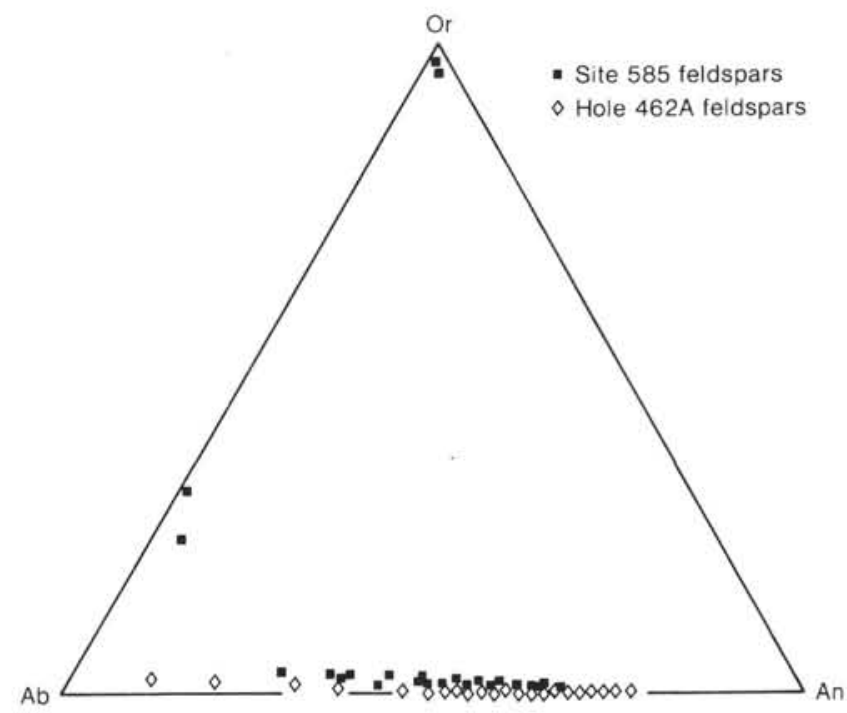

Figure 6. Compositional variation of Hole $462 \mathrm{~A}$ and Site 585 plagioclases and secondary orthoclases. 


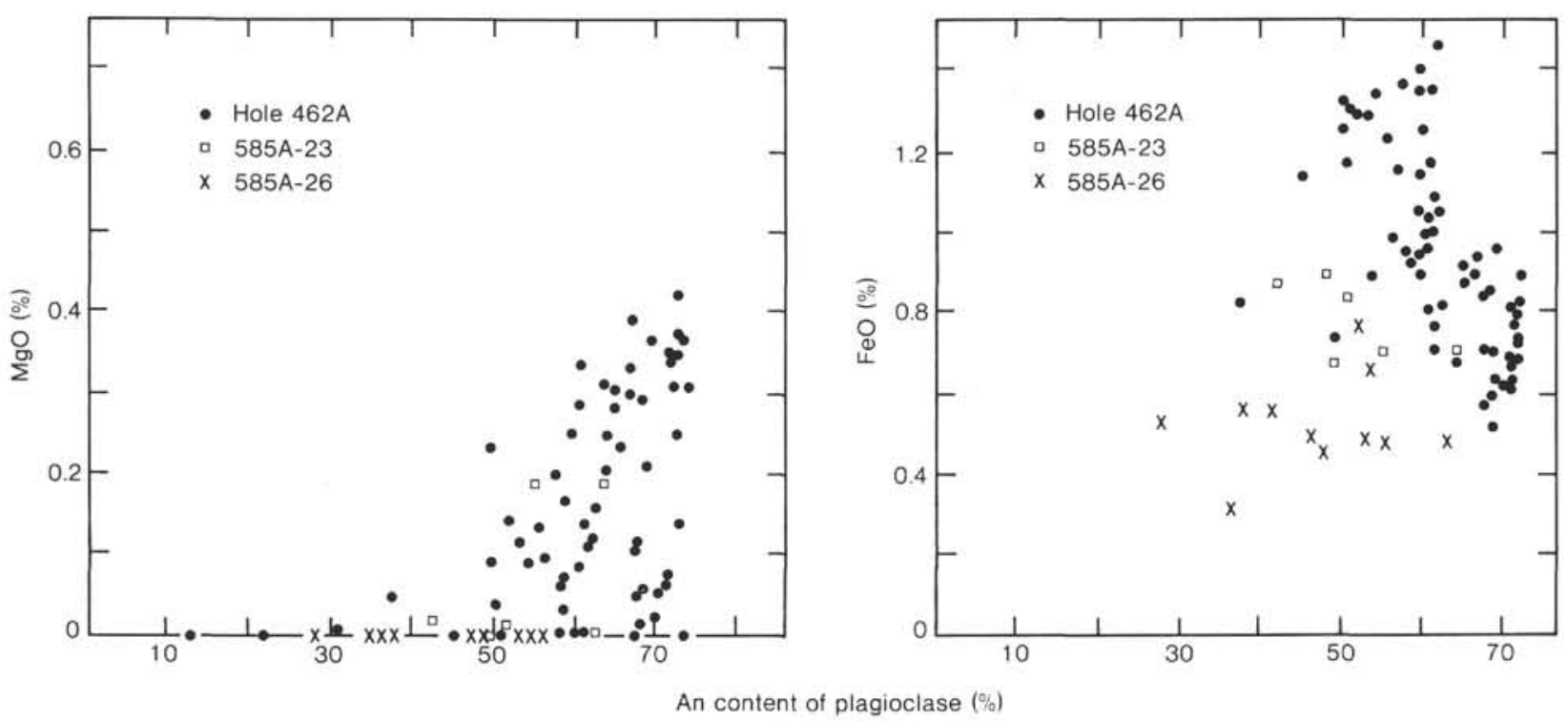

Figure 7. $\mathrm{FeO}$ and $\mathrm{MgO}$ contents in plagioclase, relative to An content. (Site 585 sample numbers are our Keele numbers; see Table 1 for corresponding DSDP sample numbers.)

crystic groups and the matrix of the coarser-grained holocrystalline flows. Because of the chemically evolved nature of these basalts and the coexistence of liquidus plagioclase and clinopyroxene, trends of increasing $\mathrm{Mg}$ with decreasing An content, displayed in some MORB containing early, highly calcic plagioclase (Bence et al., 1975), are not apparent here.

Plagioclase phenocrysts in Site 585 glassy and lithic clasts are less calcic and poor in $\mathrm{Fe}+\mathrm{Mg}$, but more potassic than Hole 462A glomerocrysts (Table 3; Figs. 6, $8)$. The phenocrysts are labradorites with average values of $\mathrm{An}_{57}$ for the core and $\mathrm{An}_{47}$ for the rims. Overall, the orthoclase component increases with decreasing An content (Fig. 6), such that, on average, cores have $\mathrm{Or}_{1.0}$ and rims $\mathrm{Or}_{1.5}$. There is some minor variation resulting from fractionation; Samples 585-48-1, 141-144 cm and 585A-
22-2, 10-14 $\mathrm{cm}$ have the highest An core contents $\left(\mathrm{An}_{62-64}\right)$. Matrix plagioclase laths from an aphyric alkali basalt clast (Samples 585A-21-1, 61-65 cm) are less calcic than the phenocrysts in the vitric clasts, and have cores of $\mathrm{An}_{53-46}$ and rims of $\mathrm{An}_{41-33}$. This sample also contains small patches of tertiary feldspars of composition $\mathrm{Ab}_{68-72} \mathrm{An}_{1-4} \mathrm{Or}_{24-31}$ (Fig. 6). Only in Sample 585A$20-2,121-123 \mathrm{~cm}$ has an almost pure orthoclase ( $\mathrm{Or}_{97-98}$ ) been identified, which, as it replaces matrix plagioclase, is a secondary alteration product.

\section{SECONDARY PHASES}

Palagonite and a variety of secondary minerals (smectites, celadonites, zeolites) were analyzed; representative data are listed in Tables 4 through 7 . Alteration locations in samples from Hole $462 \mathrm{~A}$ and Site 585 include

Table 3. Plagioclase compositions, Hole 462A (sample numbers 1-10) and Site 585 (sample numbers 11-20), Leg 89.

\begin{tabular}{|c|c|c|c|c|c|c|c|c|c|c|c|c|c|c|c|c|c|c|c|c|}
\hline & 1 & 2 & 3 & 4 & 5 & 6 & 7 & 8 & 9 & 10 & 11 & 12 & 13 & 14 & 15 & 16 & 17 & 18 & 19 & 20 \\
\hline $\mathrm{SiO}_{2}$ & 55.10 & 49.38 & 49.62 & 54.15 & 63.80 & 51.37 & 50.90 & 51.35 & 57.13 & 53.75 & 54.50 & 57.76 & 54.55 & 55.10 & 52.04 & 54.57 & 52.68 & 53.42 & 54.31 & 53.09 \\
\hline $\mathrm{TiO}_{2}$ & 0.04 & 0.00 & 0.00 & 0.08 & 0.08 & 0.05 & 0.00 & 0.00 & 0.20 & 0.00 & 0.13 & 0.15 & 0.29 & 0.22 & 0.20 & 0.10 & 0.25 & 0.24 & 0.22 & 0.01 \\
\hline $\mathrm{Al}_{2} \overline{\mathrm{O}}_{3}$ & 26.69 & 30.95 & 30.83 & 28.27 & 22.80 & 30.75 & 29.89 & 30.12 & 26.34 & 29.27 & 28.04 & 25.41 & 28.10 & 28.79 & 29.51 & 28.07 & 29.77 & 29.11 & 29.96 & 29.65 \\
\hline $\mathrm{FeO}{ }^{*}$ & 1.32 & 0.79 & 0.68 & 0.88 & 0.55 & 0.94 & 0.64 & 0.95 & 1.13 & 0.80 & 0.48 & 0.31 & 0.77 & 0.75 & 0.69 & 0.70 & 0.70 & 0.71 & 0.58 & 0.39 \\
\hline $\mathrm{MnO}$ & 0.05 & 0.20 & 0.12 & 0.00 & 0.01 & 0.02 & 0.00 & 0.00 & 0.00 & 0.00 & 0.00 & 0.06 & 0.06 & 0.02 & 0.04 & 0.00 & 0.03 & 0.00 & 0.03 & 0.00 \\
\hline $\mathrm{MgO}$ & 0.10 & 0.35 & 0.31 & 0.00 & 0.00 & 0.81 & 0.05 & 0.21 & 0.00 & 0.00 & 0.00 & 0.00 & 0.07 & 0.01 & 0.19 & 0.19 & 0.00 & 0.00 & 0.49 & 0.10 \\
\hline $\mathrm{CaO}$ & 10.29 & 14.81 & 14.78 & 11.98 & 4.27 & 14.24 & 13.96 & 14.13 & 9.32 & 12.57 & 10.91 & 7.42 & 11.87 & 11.85 & 13.10 & 11.27 & 12.96 & 12.30 & 12.50 & 13.00 \\
\hline $\mathrm{Na}_{2} \mathrm{O}$ & 5.50 & 2.87 & 3.26 & 4.94 & 9.18 & 3.45 & 3.57 & 3.79 & 5.86 & 4.23 & 5.31 & 7.06 & 4.98 & 4.70 & 4.15 & 5.11 & 4.19 & 4.63 & 4.83 & 4.23 \\
\hline $\mathrm{K}_{2} \mathrm{O}$ & 0.06 & 0.00 & 0.00 & 0.07 & 0.23 & 0.06 & 0.02 & 0.00 & 0.16 & 0.02 & 0.19 & 0.44 & 0.06 & 0.16 & 0.22 & 0.25 & 0.19 & 0.23 & 0.15 & 0.15 \\
\hline
\end{tabular}

Cations/ 8 oxygens

\begin{tabular}{|c|c|c|c|c|c|c|c|c|c|c|c|c|c|c|c|c|c|c|c|c|}
\hline $\mathrm{Si}$ & 2.516 & 2.276 & 2.282 & 2.450 & 1.802 & 2.309 & 2.343 & 2.336 & 2.567 & 2.422 & 2.474 & 2.625 & 2.456 & 2.456 & 2.370 & 2.465 & 2.380 & 2.413 & 2.396 & 2.397 \\
\hline $\mathrm{Ti}$ & 0.001 & 0.000 & 0.000 & 0.003 & 0.003 & 0.002 & 0.000 & 0.000 & 0.007 & 0.000 & 0.005 & 0.005 & 0.010 & 0.007 & 0.007 & 0.004 & 0.008 & 0.008 & 0.007 & 0.000 \\
\hline $\mathrm{Al}$ & 1.436 & 1.681 & 1.671 & 1.508 & 1.180 & 1.629 & 1.622 & 1.615 & 1.395 & 1.555 & & & & & & & & & 1.558 & 1.578 \\
\hline $\mathrm{Fe}$ & 0.051 & 0.031 & 0.026 & 0.033 & 0.020 & 0.035 & 0.025 & 0.036 & 0.042 & 0.030 & 0.0 & 12 & 29 & & 0.026 & 0.026 & 027 & 0.027 & 0.021 & .015 \\
\hline Mn & 0.002 & 0.008 & 0.005 & 0.000 & 0.000 & 0.001 & 0.000 & 0.000 & 0.000 & 0.000 & 0.000 & 0.002 & 0.002 & 0.001 & 0.002 & 0.000 & 0.001 & 0.000 & 0.000 & 0.001 \\
\hline $\mathrm{Mg}$ & 0.007 & 0.024 & 0.021 & 0.000 & 0.000 & 0.054 & 0.004 & 0.014 & 0.000 & 0.000 & 0.000 & 0.000 & 0.004 & 0.001 & 0.013 & 0.013 & 0.000 & 0.000 & 0.032 & 0.007 \\
\hline $\mathrm{Ca}$ & 0.504 & 0.731 & 0.728 & 0.581 & 0.201 & 0.686 & 0.688 & 0.689 & 0.449 & 0.607 & 0.531 & 0.361 & 0.574 & 0.566 & 0.639 & 0.545 & 0.628 & 0.595 & 0.591 & 0.629 \\
\hline $\mathrm{Na}$ & 0.487 & 0.256 & 0.290 & 0.434 & 0.782 & 0.301 & 0.318 & 0.334 & 0.511 & 0.369 & 0.468 & 0.622 & 0.434 & 0.406 & 0.366 & 0.447 & 0.367 & 0.406 & 0.413 & 0.370 \\
\hline & 0.003 & 0.000 & 0.000 & 0.004 & 0.013 & 0.003 & 0.001 & 0.000 & 0.009 & 0.001 & 0.011 & 0.025 & 0.004 & 0.009 & 0.013 & 0.014 & 0.011 & 0.013 & 0.008 & 0.009 \\
\hline
\end{tabular}

Note: Sample data: Samples 1 to 3: matrix lath, core and rim portions of microphenocryst, respectively (462A-105-11, 52-56 cm). Samples 4 to 6: core and rim portions of glomerocryst, core of glomerocryst, respectively (462A-96-2, 122-127 cm). Samples 7 to 9: core and rim portions of phenocryst, matrix lath, respectively (462A-108-3, 75-78 cm). Sample 10: matrix lath $(462 \mathrm{~A}-101-5,52-56 \mathrm{~cm})$. Samples 11, 12: core and rim portions of matrix lath in basalt clast ( $585 \mathrm{~A}-21-1,61-65 \mathrm{~cm})$. Samples $13,14:$ core and rim portions of microphenocryst in palagonite clast ( $585-51, \mathrm{CC}, 17-21 \mathrm{~cm})$. Samples 15, 16: core and rim portions of matrix lath (585A-20-2, 121-123 cm). Samples 17, 18: matrix laths (585-48-1, 141-144 cm). Samples 19, 20: rim and core portions of separate matrix laths (585A-22-2, 10-14 cm). 
A

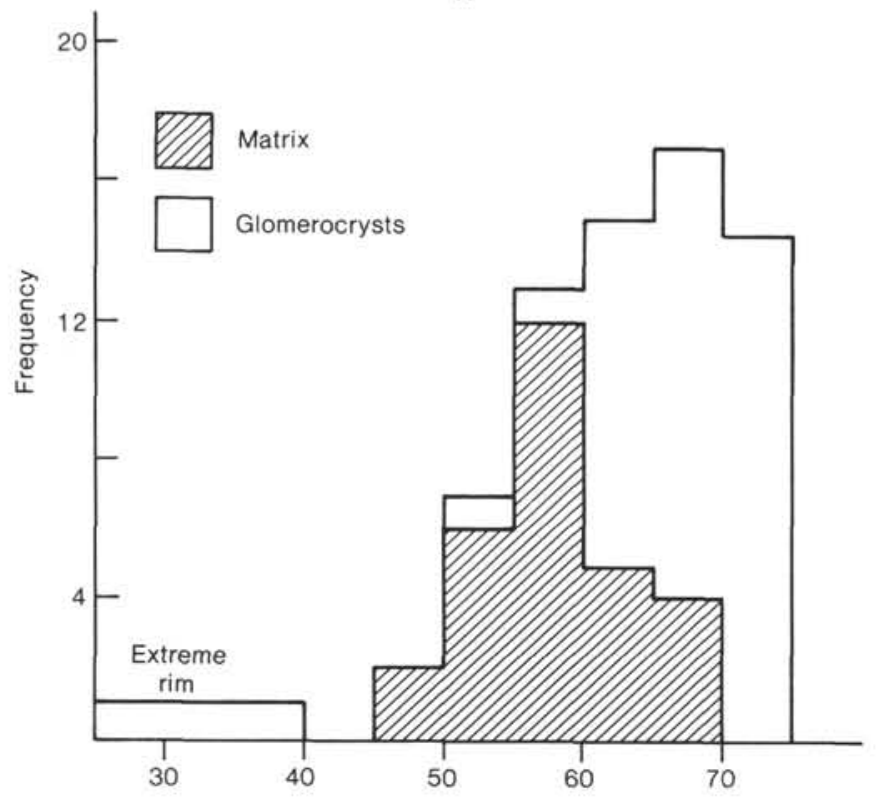

B

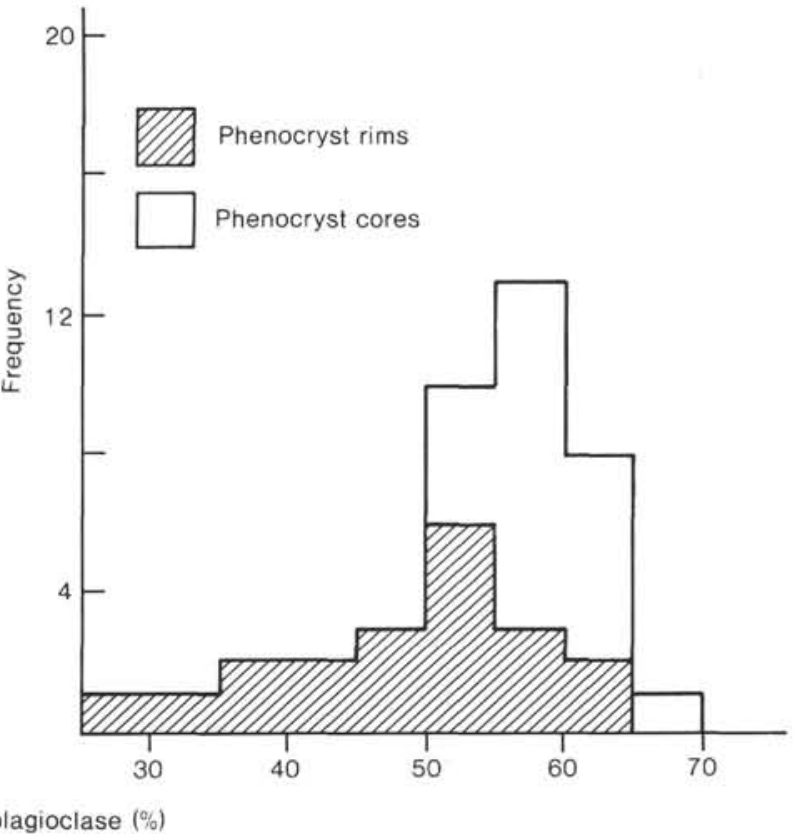

Figure 8. Distribution of An content in (A) matrix and glomerocrystic Hole 462A plagioclases and (B) the core and rim portions of Site 585 phenocrysts.

glass, plagioclase phenocrysts, and vesicle infillings, the general features of which have been described by Floyd (this volume).

\section{Palagonite}

Golden yellow-brown palagonite replacing Hole 462A basalt interstitial glass is often very Fe-rich, $\mathrm{Mg}$ - and $\mathrm{Al}$ poor (Sample 462A-105-2, 58-63 cm; Table 4) relative to the yellow-green and brown palagonitized clasts in the Site 585 volcaniclastics. Occasionally, however, the palagonite is similar in composition to the Site 585 rocks (Sample 462A-101-5, 52-56 cm; Table 4).

Although no fresh glass-palagonite pairs were available for direct chemical comparison, the palagonites commonly show the typically enhanced total $\mathrm{Fe}+\mathrm{K}$ and low $\mathrm{Mg}$ contents (Table 4) relative to fresh glass precursors noted elsewhere (e.g., Baragar et al., 1977; Scarfe and Smith, 1977; Pritchard et al., 1979).
There are clasts containing palagonite with microlites of plagioclase (Sample 585-51-CC, 17-21 cm; Table 4), and these are more Ti-rich than many of the plagioclasefree palagonites. Smectite often replaces palagonite at a late stage, and the smectite contains less $\mathrm{Ca}$ and $\mathrm{Ti}$ than the palagonite. The process of producing smectite from palagonite appears to have an anisotropic intermediate stage, which some workers have called "fibropalagonite." There is little difference in composition between smectite and "fibropalagonite," but zones often develop in which the $\mathrm{Ca}$ and $\mathrm{Ti}$ are enhanced, and these may be fine-scale intergrowths between smectite and sphene (Fig. 9).

\section{Smectites and Celadonites}

Brownish smectites replacing interstitial glass in Hole $462 \mathrm{~A}$ basalts are on the whole $\mathrm{Fe}$-rich $(\mathrm{Mg} / \mathrm{Fe}$ ratios cluster around 1.2, but can be as low as 0.5 ), and reflect the

Table 4. Palagonite compositions, Hole 462A (sample numbers 1-8) and Site 585 (sample numbers 9-18), Leg 89.

\begin{tabular}{|c|c|c|c|c|c|c|c|c|c|c|c|c|c|c|c|c|c|c|}
\hline & 1 & 2 & 3 & 4 & 5 & 6 & 7 & 8 & 9 & 10 & 11 & 12 & 13 & 14 & 15 & 16 & 17 & 18 \\
\hline $\mathrm{SiO}_{2}$ & 44.58 & 43.36 & 45.32 & 43.92 & 45.43 & 45.50 & 46.36 & 45.15 & 36.84 & 35.68 & 42.73 & 42.29 & 38.91 & 38.17 & 38.55 & 40.02 & 41.46 & 40.46 \\
\hline $\mathrm{TiO}_{2}$ & 0.22 & 0.00 & 0.87 & 0.85 & 0.76 & 0.32 & 0.31 & 0.70 & 2.09 & 2.52 & 0.07 & 0.18 & 0.51 & 2.51 & 4.03 & 0.75 & 1.88 & 1.48 \\
\hline $\mathrm{Al}_{2} \mathrm{O}_{3}$ & 6.61 & 6.20 & 3.24 & 3.14 & 3.07 & 3.63 & 3.28 & 3.27 & 7.76 & 7.51 & 10.16 & 9.79 & 7.72 & 7.67 & 7.96 & 10.18 & 9.34 & 8.75 \\
\hline $\mathrm{FeO}^{*}$ & 21.77 & 21.85 & 28.65 & 27.61 & 28.50 & 28.26 & 28.70 & 28.18 & 14.98 & 14.95 & 15.78 & 15.57 & 14.96 & 17.11 & 15.86 & 20.37 & 15.74 & 15.66 \\
\hline $\mathrm{MnO}$ & 0.08 & 0.13 & 0.25 & 0.28 & 0.23 & 0.28 & 0.30 & 0.20 & 0.07 & 0.26 & 0.32 & 0.20 & 0.22 & 0.18 & 0.33 & 0.23 & 0.20 & 0.37 \\
\hline $\mathrm{MgO}$ & 12.89 & 12.85 & 2.37 & 2.28 & 2.17 & 2.70 & 2.20 & 2.79 & 11.33 & 10.59 & 8.84 & 9.02 & 14.02 & 10.84 & 10.86 & 12.61 & 11.71 & 12.42 \\
\hline $\mathrm{CaO}$ & 2.86 & 2.55 & 4.73 & 4.54 & 4.78 & 4.60 & 4.80 & 4.59 & 4.84 & 5.07 & 2.86 & 2.85 & 3.68 & 5.32 & 6.47 & 3.32 & 3.47 & 3.85 \\
\hline $\mathrm{Na}_{2} \mathrm{O}$ & 0.71 & 0.49 & 0.06 & 0.11 & 0.00 & 0.16 & 0.38 & 0.53 & 0.67 & 0.17 & 0.94 & 0.82 & 0.87 & 0.85 & 0.87 & 1.27 & 0.73 & 0.88 \\
\hline $\mathrm{K}_{2} \mathrm{O}$ & 0.11 & 0.10 & 0.11 & 0.12 & 0.09 & 0.12 & 0.16 & 0.17 & 0.06 & 0.08 & 1.71 & 1.80 & 0.13 & 0.03 & 0.03 & 0.06 & 0.76 & 0.72 \\
\hline Total & 89.83 & 87.53 & 85.60 & 82.85 & 85.03 & 85.57 & 87.49 & 85.58 & 78.64 & 76.83 & 83.41 & 82.52 & 81.02 & 82.68 & 84.96 & 88.81 & 85.29 & 84.59 \\
\hline
\end{tabular}

Note: Sample data: Samples 1, 2: interstitial palagonitized glass in massive aphyric basalt (462A-101-5, 52-56 cm). Samples 3 to 8 : interstitial palagonitized glass in quenched aphyric basalt (462A-105-2, 58-63 cm). Samples 9 to 13: palagonite shards in lithic-vitric tuff (585-51,CC, 17-21 cm). Samples 14 to 18 : plagioclase phyric palagonite clasts in lithic-vitric tuff (585A-22-2, 10-14 cm). 
A

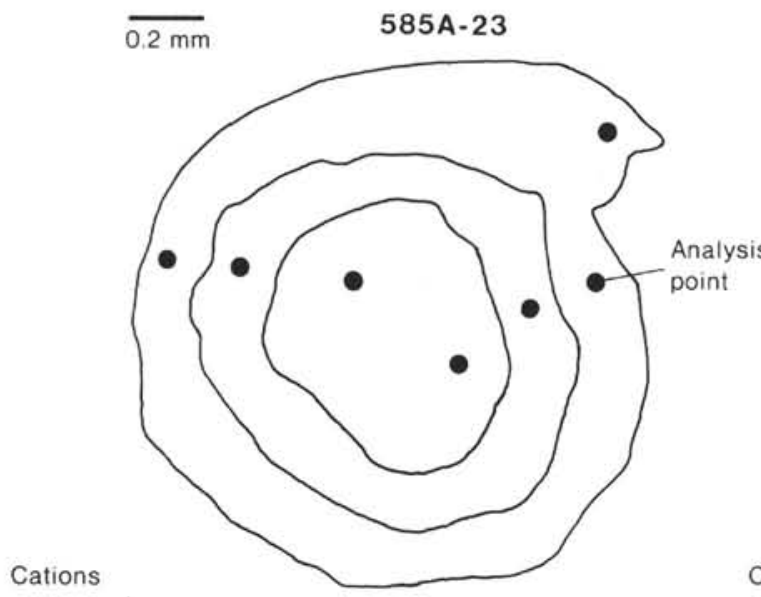

B

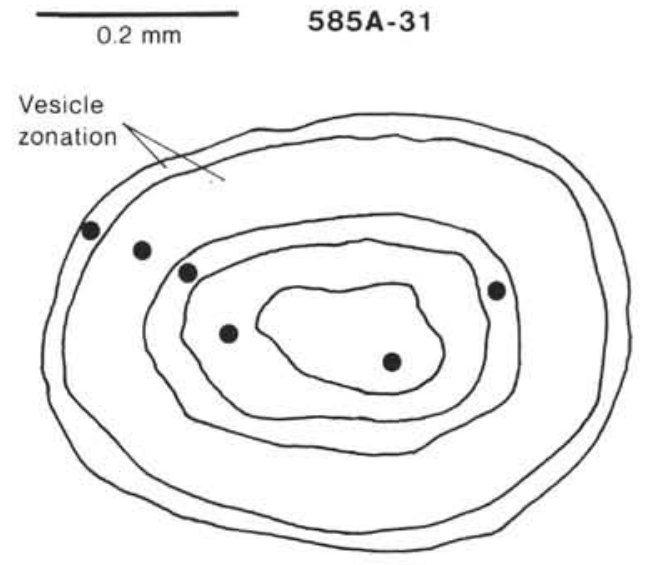

Cations

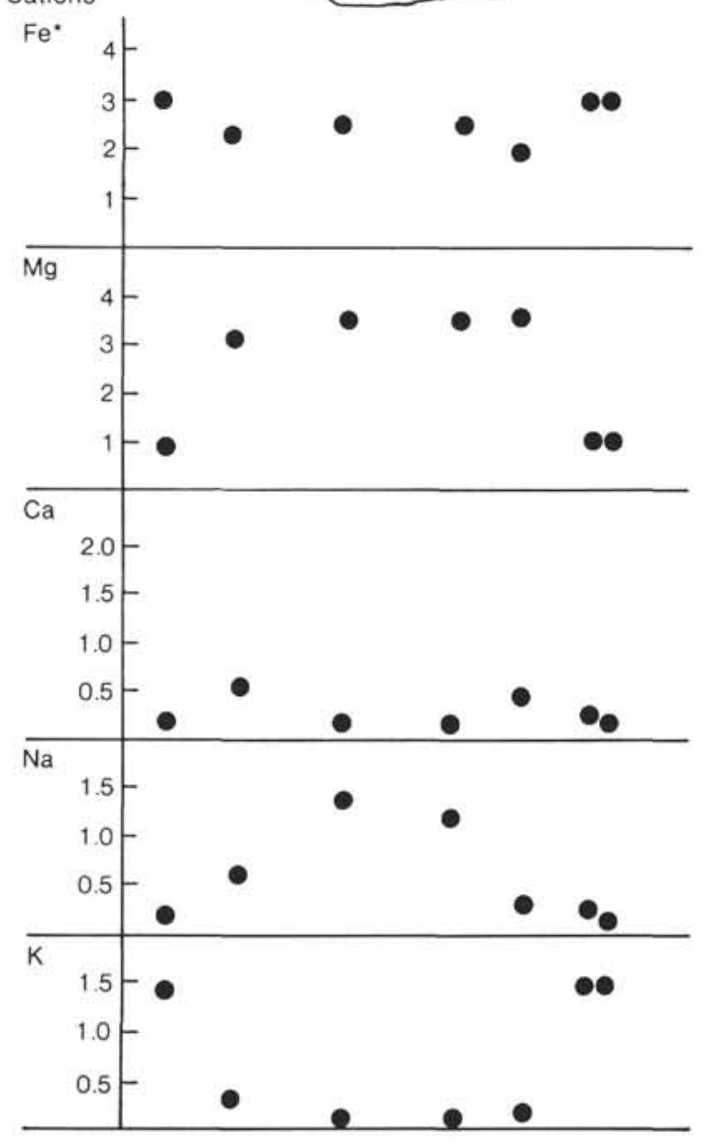

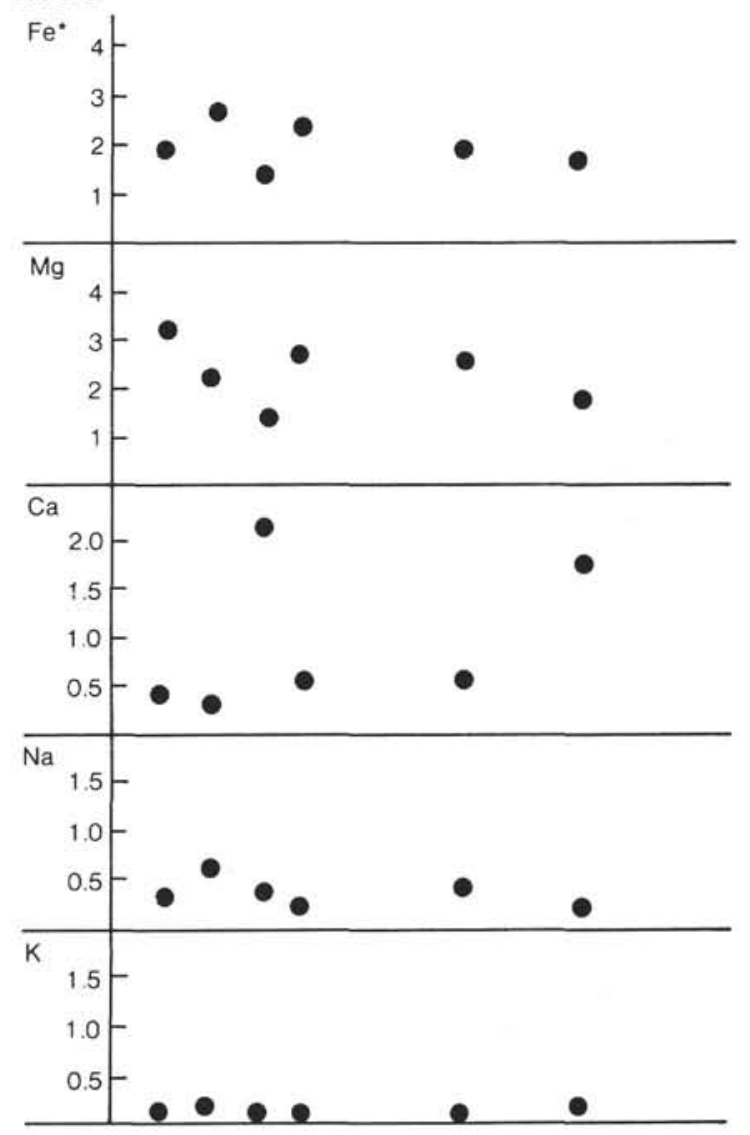

Relative distance between analysis points

Figure 9. Chemical variation across the zoned infillings of vesicles in (A) Site 585 lithic clast and (B) Site 585 vitric clast. Sketches show positions of analysed points in vesicle traverse. (Sample numbers shown are our Keele numbers; see Table 1 for corresponding DSDP sample numbers.)

bulk rock composition (average $\mathrm{FeO}^{*}=12.5$ wt.\%) and the development of Fe-rich residual liquids. Minor differences in $\mathrm{Mg} / \mathrm{Fe}$ ratio are, however, apparent between dark smectites replacing glass in quenched flow margins and smectite after residual interstitial glass in massive basalts (Fig. 10). Although optical properties, especially color, are not particularly reliable as guides to smectite composition, some studies indicate that pale col- ored smectites tend to be Mg-rich (e.g., Scheidegger and Stakes, 1977; Pritchard, 1980), whereas darker brownish varieties have higher $\mathrm{Fe}^{3+} / \mathrm{Fe}^{2+}$ ratios (Ross and Hendricks, 1945). Although the oxidation ratio of the brown Fe-rich smectites analyzed here is unknown, it is inferred that the darkest smectites are probably the most oxidized. The assumption is based on the observation that the dark brown smectites replace glass that is in- 

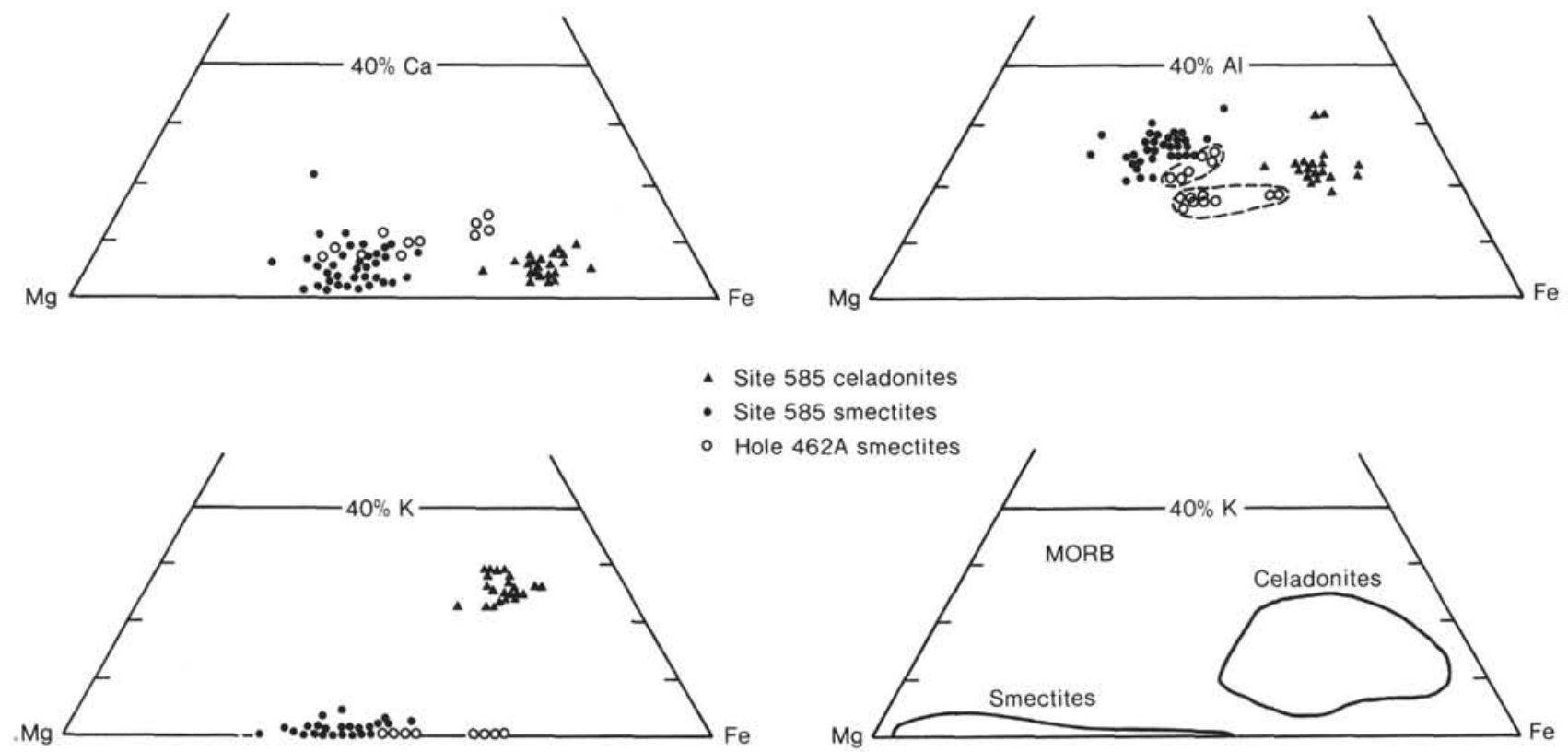

Site 585 celadonites

- Site 585 smectites

Hole 462A smectites

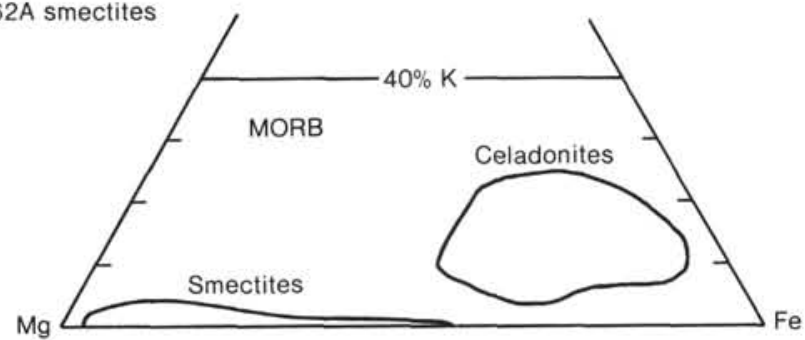

Figure 10. Chemical characteristics of Hole 462A and Site 585 smectites and celadonites. Comparative data for MORB smectites and celadonites from Andrews (1977), Robinson et al. (1977), and Humphris, Melson, et al. (1980).

Table 5. Smectite compositions, Hole 462A (sample numbers 1-10) and Site 585 (sample numbers 11-20), Leg 89.

\begin{tabular}{|c|c|c|c|c|c|c|c|c|c|c|c|c|c|c|c|c|c|c|c|c|}
\hline & 1 & 2 & 3 & 4 & 5 & 6 & 7 & 8 & 9 & 10 & 11 & 12 & 13 & 14 & 15 & 16 & 17 & 18 & 19 & 20 \\
\hline $\mathrm{SiO}_{2}$ & 35.80 & 34.96 & 42.79 & 42.24 & 39.22 & 43.98 & 43.26 & 45.21 & 45.12 & 45.96 & 34.01 & 39.43 & 38.02 & 37.50 & 36.05 & 37.31 & 32.32 & 35.67 & 37.16 & 37.62 \\
\hline $\mathrm{TiO}_{2}$ & 0.29 & 0.49 & 0.23 & 0.06 & 0.07 & 0.49 & 0.47 & 0.20 & 0.30 & 0.39 & 0.18 & 0.11 & 0.14 & 0.21 & 0.00 & 0.15 & 0.00 & 0.07 & 0.16 & 0.45 \\
\hline $\mathrm{Al}_{2} \mathrm{O}_{3}$ & 9.51 & 9.24 & 6.38 & 5.68 & 6.24 & 6.02 & 5.63 & 4.86 & 5.15 & 5.25 & 8.94 & 10.45 & 9.52 & 9.28 & 12.28 & 8.25 & 12.31 & 10.21 & 7.25 & 7.07 \\
\hline $\mathrm{FeO}^{-3}$ & 25.14 & 25.46 & 20.78 & 20.14 & 20.29 & 24.75 & 24.70 & 10.76 & 21.92 & 22.43 & 19.84 & 23.04 & 24.20 & 14.21 & 17.83 & 15.46 & 22.92 & 17.32 & 15.07 & 14.56 \\
\hline $\mathrm{MnO}$ & 0.00 & 0.08 & 0.08 & 0.01 & 0.04 & 0.00 & 0.14 & 0.14 & 0.01 & 0.01 & 0.33 & 0.25 & 0.36 & 0.17 & 0.18 & 0.12 & 0.01 & 0.08 & 0.26 & 0.20 \\
\hline $\mathrm{MgO}$ & 7.64 & 7.01 & 12.83 & 12.42 & 10.99 & 10.96 & 11.29 & 14.06 & 12.92 & 13.41 & 9.52 & 10.30 & 9.76 & 14.15 & 14.82 & 11.13 & 14.89 & 16.06 & 13.42 & 13.24 \\
\hline $\mathrm{CaO}$ & 4.26 & 4.24 & 4.50 & 2.48 & 2.56 & 3.16 & 3.10 & 3.49 & 2.82 & 2.68 & 6.13 & 2.82 & 3.55 & 2.38 & 2.01 & 2.84 & 1.17 & 1.89 & 4.23 & 2.70 \\
\hline $\mathrm{Na}_{2} \mathrm{O}$ & 0.54 & 0.34 & 0.78 & 0.48 & 0.85 & 0.64 & 0.53 & 0.24 & 0.58 & 0.68 & 1.94 & 1.97 & 1.02 & 1.05 & 1,11 & 1.80 & 0.49 & 0.43 & 0.73 & 1.14 \\
\hline $\mathrm{K}_{2} \mathrm{O}$ & 0.19 & 0.18 & 0.05 & 0.01 & 0.08 & 0.42 & 0.59 & 0.29 & 0.14 & 0.20 & 0.25 & 0.53 & 0.00 & 0.13 & 0.06 & 1.17 & 0.13 & 0.04 & 0.18 & 0.12 \\
\hline $\mathrm{Cr}_{2} \mathrm{O}_{3}$ & 0.00 & 0.00 & 0.07 & 0.00 & 0.00 & 0.05 & 0.03 & 0.05 & 0.15 & 0.04 & 0.00 & 0.00 & 0.00 & 0.00 & 0.15 & 0.10 & 0.07 & 0.06 & 0.00 & 0.00 \\
\hline
\end{tabular}

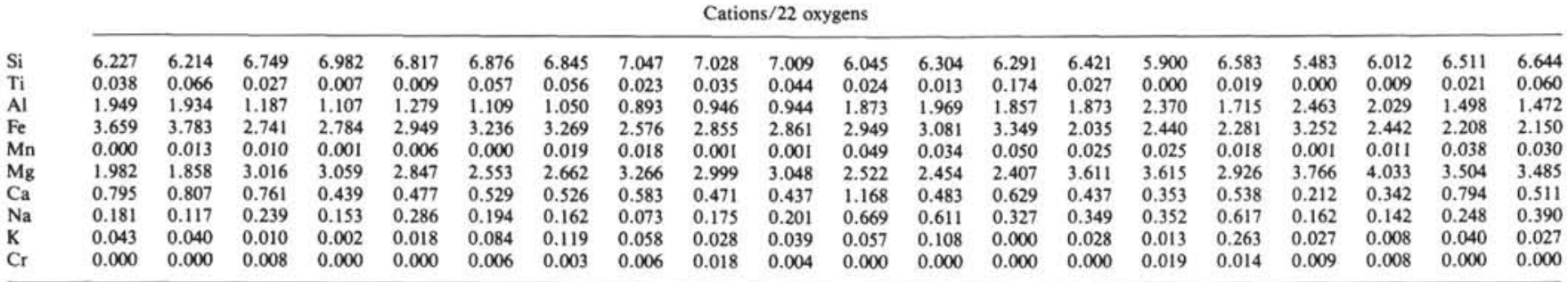

Note: Sample data: Samples 1, 2: replacing interstitial glass (462A-108-3, $75-78 \mathrm{~cm}$ ). Samples 3 to 5: replacing glass between variolites (462A-105-11, $52-56 \mathrm{~cm})$. Samples 6 to $8:$ replacing interstitial glass (462A-96-2, 122-127 cm). Samples 9, 10: replacing interstitial glass in coarse-grained matrix (462A-105-2, 58-63 cm). Samples 11 to 13: replacing palagonite clasts (585A$22-2,10-14 \mathrm{~cm}$ ). Samples 14, 15: brown and green smectite, respectively, in rim portions of different vesicles in glass clasts (585A-13-5, 13-17 cm). Sample 16: in zoned vesicle of basalt clast (585A-20-2, 121-123 cm). Samples 17, 18: green and brown smectite, respectively, replacing originally glassy matrix of clasts (585-54-2, 58-62 cm). Samples 19, 20: brown fibers replacing palagonite clasts $(585-51, \mathrm{CC}, 17-21 \mathrm{~cm})$.

variably peppered with late magnetite crystallites, whereas paler brown smectites form only from magnetite-free residual glass.

In Hole 585 volcaniclastic sediments, pale yellow and greenish smectites may totally replace vitric clasts, form concentric zones infilling vesicles, and compose the majority of a fine-grained, originally vitric, matrix. Bright green or blue-green pleochroic celadonite generally replaced plagioclase microphenocrysts and megaphenocrysts in glassy and lithic clasts, and also formed the cen- tral portion of large zoned vesicles. The yellow and green smectites are less $\mathrm{Fe}$-rich, with higher $\mathrm{Mg} / \mathrm{Fe}$ ratios (average of 1.55 in Sample $585-20-2,121-123 \mathrm{~cm}$ ) than the brown Hole 462A smectites (Fig. 10). Compared with smectites from ocean-floor basalts produced by lowgrade alteration, both the Hole $462 \mathrm{~A}$ and Site $585 \mathrm{smec}-$ tites are relatively $\mathrm{Fe}$-rich, with low $\mathrm{Mg} / \mathrm{Fe}$ ratios (Fig. 8). Mg-rich saponites appear to be typical of MORB alteration (Andrews, 1977; Humphris, Melson, et al., 1980), and relative to the composition of the smectites 
analyzed here probably reflect differences in bulk chemical composition; the Leg 89 basalts (and glass) have generally lower $\mathrm{MgO}$ contents than MORB.

Irrespective of the alteration location, the smectite compositions are very similar and show little variation, even between smectite replacing glass and that infilling vesicles.

The celadonites in this study are similar to others formed by low-grade seawater alteration of basalt; they have an average $\mathrm{K}_{2} \mathrm{O}$ content of $6.3 \mathrm{wt} . \%$, compared with 7.1 wt. $\% \mathrm{~K}_{2} \mathrm{O}$ for average celadonite (Weaver and Pollard, 1975) and 9.6 wt $\% \mathrm{~K}_{2} \mathrm{O}$ for high-potassium celadonite in Peru Trench tholeiites (Scheidegger and Stakes, 1977). Again, location does not appear to have influenced composition, since celadonites replacing plagioclase and those infilling vesicle cores are essentially similar. This is evident in the close clustering of compositions in Figure 10.

In Site 585 palagonitized shards, concentrically zoned vesicle infillings with pale yellow and green smectite rims and celadonite cores indicate a relatively sharp change in the chemistry of the depositing solutions, from initially $\mathrm{Mg}$-rich to later $(\mathrm{Fe}+\mathrm{K})$-rich. These mineralogical and chemical changes are by no means universal, however; some of the large vesicular basaltic clasts exhibit the reverse, with bright apple-green celadonite rims and dark brown or black $\mathrm{Mg}$-rich smectite cores. Some of the latter chemical changes are illustrated in Figure 9; although the chemical changes are distinct, the mineralogical effects are gradational, not the result of replacement. Vesicle zonation similar to that just described has been noted by Andrews et al. (1977), Pritchard et al. (1979), Humphris, Thompson, et al. (1980), and Humphris, Melson, et al. (1980). Because celadonites contain a high proportion of oxidized Fe relative to reduced $\mathrm{Fe}$ (Weaver and Pollard, 1975), the mineralogical change from (say) smectite to celadonite in some of the Site 585 vesicles implies more strongly oxidizing conditions. In

Table 6. Celadonite compositions of Site 585 volcaniclastic samples, Leg 89 .

\begin{tabular}{lrrrrrrrrrr}
\hline & 1 & \multicolumn{1}{c}{2} & \multicolumn{1}{c}{3} & \multicolumn{1}{c}{4} & 5 & 6 & 7 & 8 & 9 & 10 \\
\hline $\mathrm{SiO}_{2}$ & 42.74 & 46.93 & 45.34 & 47.71 & 45.58 & 44.82 & 43.06 & 48.42 & 44.32 & 44.90 \\
$\mathrm{TiO}_{2}$ & 0.00 & 0.03 & 0.87 & 0.54 & 0.22 & 0.08 & 0.75 & 0.39 & 0.04 & 0.05 \\
$\mathrm{Al}_{2} \mathrm{O}_{3}$ & 5.37 & 4.40 & 9.59 & 7.02 & 5.67 & 6.30 & 8.83 & 6.24 & 6.30 & 5.40 \\
$\mathrm{FeO}^{*}$ & 21.91 & 20.80 & 21.94 & 20.21 & 21.08 & 20.64 & 20.68 & 20.91 & 20.32 & 19.16 \\
$\mathrm{MnO}$ & 0.04 & 0.00 & 0.00 & 0.12 & 0.14 & 0.10 & 0.01 & 0.08 & 0.05 & 0.09 \\
$\mathrm{MgO}$ & 2.85 & 3.88 & 3.71 & 6.39 & 4.42 & 4.99 & 3.29 & 4.63 & 3.80 & 4.11 \\
$\mathrm{CaO}$ & 2.31 & 0.99 & 1.89 & 1.19 & 1.26 & 1.69 & 1.50 & 0.93 & 1.05 & 0.79 \\
$\mathrm{Na}_{2} \mathrm{O}$ & 0.23 & 0.40 & 0.99 & 0.80 & 0.38 & 0.83 & 0.70 & 0.37 & 0.52 & 0.49 \\
$\mathrm{~K}_{2} \mathrm{O}$ & 6.44 & 7.32 & 6.07 & 5.96 & 6.09 & 5.50 & 5.73 & 6.44 & 6.59 & 6.89 \\
\hline
\end{tabular}

\begin{tabular}{lllllllllll} 
& \multicolumn{10}{c}{ Cations/22 oxygens } \\
\cline { 2 - 12 } $\mathrm{Si}$ & 7.560 & 7.883 & 7.141 & 7.443 & 7.629 & 7.481 & 7.231 & 7.698 & 7.595 & 7.756 \\
$\mathrm{Ti}$ & 0.000 & 0.004 & 0.103 & 0.063 & 0.027 & 0.010 & 0.095 & 0.047 & 0.005 & 0.006 \\
$\mathrm{Al}$ & 1.119 & 0.871 & 1.781 & 1.291 & 1.119 & 1.239 & 1.748 & 1.170 & 1.273 & 1.100 \\
$\mathrm{Fe}$ & 3.241 & 2.921 & 2.890 & 2.637 & 2.950 & 2.880 & 2.904 & 2.780 & 2.912 & 2.768 \\
$\mathrm{Mn}$ & 0.006 & 0.000 & 0.000 & 0.016 & 0.019 & 0.015 & 0.001 & 0.011 & 0.007 & 0.013 \\
$\mathrm{Mg}$ & 0.750 & 0.972 & 0.871 & 1.485 & 1.102 & 1.240 & 0.823 & 1.097 & 0.971 & 1.058 \\
$\mathrm{Ca}$ & 0.438 & 0.178 & 0.320 & 0.199 & 0.225 & 0.303 & 0.270 & 0.158 & 0.193 & 0.144 \\
$\mathrm{Na}$ & 0.078 & 0.129 & 0.301 & 0.243 & 0.124 & 0.269 & 0.228 & 0.114 & 0.173 & 0.164 \\
$\mathrm{~K}$ & 1.452 & 1.568 & 1.220 & 1.186 & 1.300 & 1.172 & 1.228 & 1.306 & 1.441 & 1.518 \\
\hline
\end{tabular}

Note: Sample data: Samples 1, 2: from 585A-20-2, 121-123 cm; rim of vesicle in basalt clast. Samples 3, 4: from $585-48-1,141-144 \mathrm{~cm}$; replacing plagioclase megaphenocryst. Samples 5,6 : from 585A-22-2, 10-14 cm; infilling vesicles in glassy clasts. Samples 7, 8: from 585-48-1, $141-144 \mathrm{~cm}$; replacing plagioclase phenocrysts. Samples 9 , 10: from $585 \mathrm{~A}-20-2,121-123 \mathrm{~cm}$ replacing plagioclase(?) in matrix and infilling vesicle, respectively, in basalt clast. this case, however, the general lack of oxides in the Site 585 clasts suggests that the degree of oxidation was low.

Oxygen-isotope data for celadonites and Fe-rich smectites suggest that formation temperatures were probably low $\left(0-35^{\circ} \mathrm{C}\right.$; Seyfried et al., 1978; Stakes and O'Neil, 1982), indicative of deposition from cold seawater.

\section{Zeolites}

Table 7 shows analyses of a zeolite replacing the smectite matrix of Site 585 clasts. Zeolites may also replace both smectite and celadonite in phenocrysts and zoned vesicles, in which case they would have formed at a relatively late stage, under conditions more oxidizing than previously. The particular samples probed are phillipsites, the presence of which has been confirmed by X-ray diffraction (XRD) analysis (Site 585 chapter, this volume). The analyzed phillipsites show a wide range of alkali contents, which is a common characteristic of this zeolite, although the compositions depart markedly from ideality, where $2 \mathrm{Ca}+\mathrm{Na}+\mathrm{K}=\mathrm{Al}$ (Fig. 11). Some have compositions similar to those analyzed by Scarfe and Smith (1976) from Leg 37 basalts, although in this case some of the variation is probably due to alkali volatilization during analysis, even though a defocused beam was used.

\section{CONCLUSIONS}

1. Glomerocrystic clinopyroxenes in Hole $462 \mathrm{~A}$ sheetflow basalts are typical tholeiitic augites with rims fractionated to ferroaugites. Quench-textured clinopyroxenes in rapidly chilled flows exhibit metastable trends of decreasing $\mathrm{Ca}$, towards subcalcic augite. All the pyroxenes are characterized by low Ti contents, and in this respect reflect the low bulk-rock content. Free-floating clinopyroxene megacrysts and phenocrysts in lithic clasts in Site 585 volcaniclastic sediments are represented by both alkaline diopside-salite-calcic augite compositions and tholeiitic augites. The pyroxene compositions indicate the

Table 7. Phillipsite (samples 1-7) and analcite (samples 8, 9) compositions, Site 585, Leg 89.

\begin{tabular}{|c|c|c|c|c|c|c|c|c|c|}
\hline & 1 & 2 & 3 & 4 & 5 & 6 & 7 & 8 & 9 \\
\hline $\mathrm{SiO}_{2}$ & 51.11 & 50.03 & 52.13 & 54.00 & 55.26 & 51.45 & 53.89 & 54.71 & 55.82 \\
\hline $\mathrm{TiO}_{2}$ & 0.77 & 0.79 & 0.60 & 0.00 & 0.00 & 0.00 & 0.78 & 0.00 & 0.00 \\
\hline $\mathrm{Al}_{2} \mathrm{O}_{3}$ & 23.05 & 22.88 & 23.53 & 22.02 & 21.98 & 22.45 & 24.00 & 21.84 & 22.33 \\
\hline $\mathrm{FeO} 0^{\circ}$ & 0.33 & 0.40 & 0.39 & 0.01 & 0.06 & 0.18 & 0.23 & 0.12 & 0.00 \\
\hline $\mathrm{MnO}$ & 0.00 & 0.00 & 0.00 & 0.00 & 0.00 & 0.10 & 0.00 & 0.11 & 0.00 \\
\hline $\mathrm{MgO}$ & 0.00 & 0.00 & 0.00 & 0.05 & 0.00 & 0.09 & 0.19 & 0.00 & 0.00 \\
\hline $\mathrm{CaO}$ & 5.34 & 5.39 & 5.07 & 6.59 & 4.56 & 3.95 & 4.40 & 0.03 & 0.23 \\
\hline $\mathrm{Na}_{2} \mathrm{O}$ & 1.92 & 2.13 & 4.99 & 7.33 & 9.14 & 3.32 & 2.53 & 12.76 & 12.40 \\
\hline \multirow[t]{2}{*}{$\mathrm{K}_{2} \mathrm{O}$} & 3.53 & 5.39 & 3.79 & 0.43 & 0.27 & 2.40 & 3.00 & 0.05 & 0.00 \\
\hline & \multicolumn{7}{|c|}{ Cations/ 72 oxygens } & \multicolumn{2}{|c|}{$\begin{array}{l}\text { Cations/ } \\
6 \text { oxygens }\end{array}$} \\
\hline $\mathbf{S i}$ & 23.857 & 23.495 & 23.490 & 24.079 & 24.356 & 24.379 & 24.107 & 2.043 & 2.050 \\
\hline $\mathrm{Ti}$ & 0.270 & 0.278 & 0.204 & 0.000 & 0.000 & 0.000 & 0.262 & 0.000 & 0.000 \\
\hline Al & 12.684 & 12.668 & 12.500 & 11.575 & 11.421 & 12.541 & 12.657 & 0.962 & 0.967 \\
\hline $\mathrm{Fe}$ & 0.129 & 0.157 & 0.146 & 0.003 & 0.020 & 0.071 & 0.086 & 0.003 & 0.000 \\
\hline $\mathrm{Mn}$ & 0.000 & 0.000 & 0.000 & 0.000 & 0.000 & 0.040 & 0.000 & 0.003 & 0.000 \\
\hline $\mathrm{Mg}$ & 0.000 & 0.000 & 0.000 & 0.035 & 0.000 & 0.064 & 0.127 & 0.000 & 0.000 \\
\hline $\mathrm{Ca}$ & 2.670 & 2.712 & 2.445 & 3.148 & 2.153 & 2.005 & 2.109 & 0.001 & 0.009 \\
\hline $\mathrm{Na}$ & 1.738 & 1.939 & 4.361 & 6.338 & 7.812 & 3.050 & 2.194 & 0.923 & 0.882 \\
\hline $\mathrm{K}$ & 2.102 & 3.229 & 2.180 & 0.244 & 0.153 & 1.451 & 1.712 & 0.002 & 0.000 \\
\hline
\end{tabular}

Note: Sample data: Samples 1 to 7: phillipsites from 585-51,CC, 17-21 cm and 585A-13-5, 13-17 $\mathrm{cm}$ replacing smectitic matrix and infilling vesicles. Samples 8, 9: analcites from 585A-22-2, $10-14 \mathrm{~cm}$ replacing matrix smectite. 

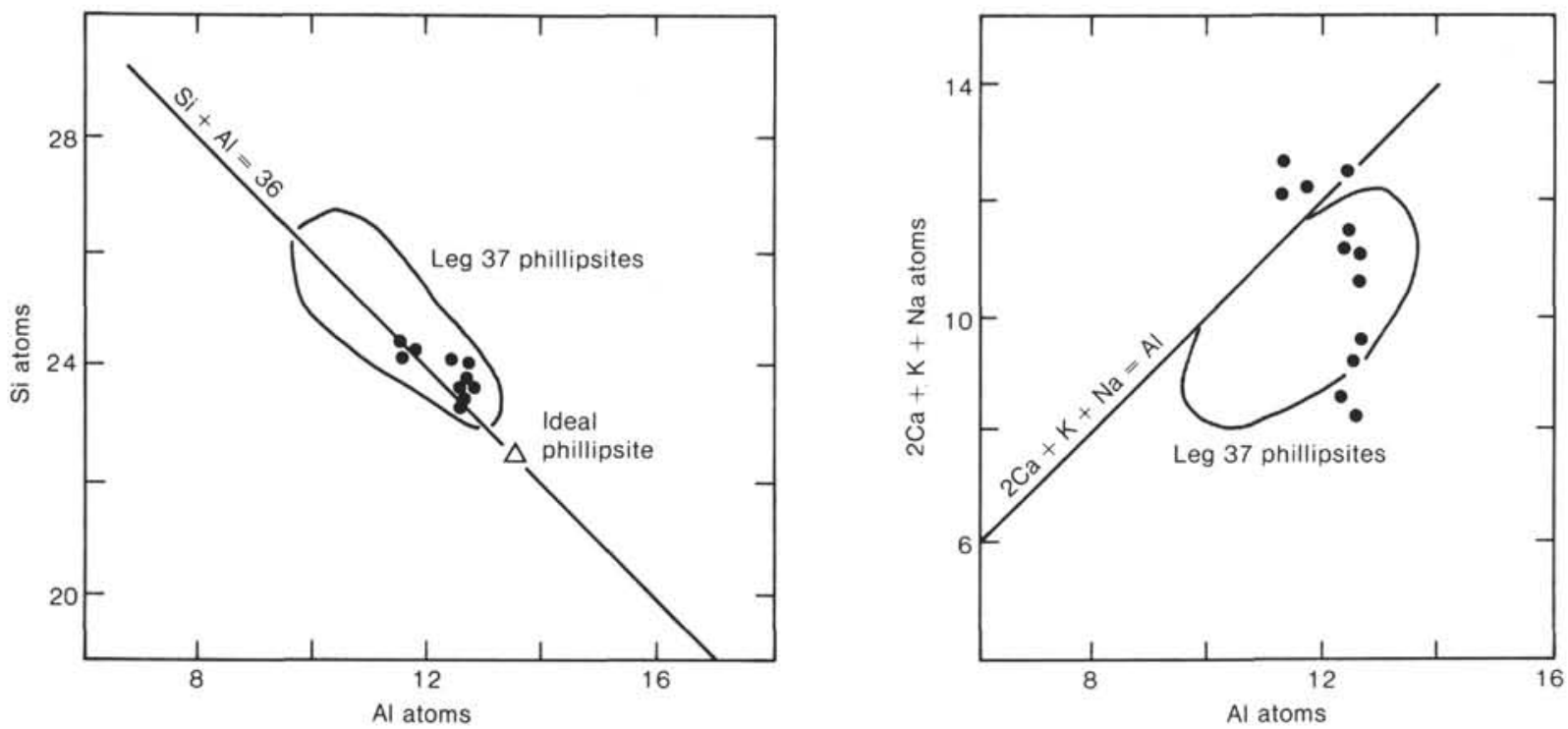

Figure 11. Variable composition of phillipsite replacing smectitic matrix of Site 585 clasts. The departure from ideality $(\mathrm{Si}+\mathrm{Al}=36$ $2 \mathrm{Ca}+\mathrm{Na}+\mathrm{K}=\mathrm{Al}$ ) is probably due to alkali volatization during analysis. Leg 37 phillipsites from Scarfe and Smith (1977).

association of tholeiitic and alkaline magmas during latestage seamount edifice-building.

2. Phenocryst and matrix plagioclase compositions are predominantly labradoritic in both Hole $462 \mathrm{~A}$ basalts and Site 585 clasts, although some glomerocrysts are zoned with bytownite cores and highly albitic rims in the sheet-flows. The more sodic compositions are richer in the orthoclase component, although this component is very low in all plagioclase. However, Site 585 plagioclases as a group have higher $\mathrm{K}$ contents than Hole 462A plagioclases, and reflect the primary K-rich nature of the volcaniclastics relative to the sheet-flow basalts.

3. Palagonite composition is variable, and appears to depend upon whether the original glass was quenched early or was late-stage and interstitial. The development of smectite from palagonite involves an intermediatestage development of "fibropalagonite," which concomitantly produces fine-scale intergrowths of smectite and sphene.

4. Brown, green, and yellow smectites from both Hole 462A samples and Site 585 samples are Fe-rich relative to smectites associated with altered MORB, irrespective of alteration site. Brown smectites replacing residual glass in basaltic sheet-flows have the highest Fe contents. Celadonites have a narrow compositional range, but have higher $\mathrm{K}$ contents than typical MORB celadonites. Compositionally zoned vesicle infillings from smectite rims to celadonite cores, or vice versa, indicate a marked change in the chemistry of the depositing solutions under progressively changing oxidizing conditions.

5 . The analyzed zeolites replacing the smectite matrix of clasts are phillipsites with variable alkali contents. These, zeolites, together with celadonite and palagonite, represent a major repository for $\mathrm{K}$ derived from seawater during the alteration process.

\section{ACKNOWLEDGMENTS}

The analyses were performed on the electron microprobe facility in the Geology Department, University of Manchester, and we are grate- ful to Professor J. Zussman for permission to use the instrument. Analysis costs were defrayed by the University of Keele Research Fund. We thank Tim Hopkins and Dave Plant for keeping the Cameca microprobe in such good working order. For helpful comments, thanks are due Dr. A. Saunders and an anonymous reviewer.

\section{REFERENCES}

Andrews, A. J., 1977. Low-temperature fluid alteration of oceanic layer 2 basalts, DSDP Leg 37. Can. J. Earth. Sci., 14:911-926.

Andrews, A. J., Barnett, R. L., MacClement, B. A. E., Fyfe, W. S., Morrison, G., et al., J., 1977. Zeolite facies metamorphism, geochemistry and some aspects of trace element redistribution in altered basalts of DSDP Leg 37. In Aumento, F., Melson, W. G., et al., Init. Repts. DSDP, 37: Washington (U.S. Govt. Printing Office), 795-810.

Baragar, W. R. A., Plant, A. G., Pringle, G. J., and Mikkel, S., 1977. Petrology and alteration of selected units of Mid-Atlantic Ridge basalts sampled from Sites 332 and 335, DSDP. Can. J. Earth Sci., $14: 837-874$.

Batiza, R., Larson, R. L., Schlanger, S. O., Shcheka, S. A., and Tokuyama, H., 1980. Trace element abundances in basalts of the Nauru Basin. Nature (London), 286:476-478.

Bence, A. E., Papike, J. J., and Ayuso, R. A., 1975. Petrology of submarine basalts from the central Caribbean: DSDP Leg 15. J. Geophys. Res., 80:4775-4804.

Clague, D. A., Fisk, M. R., and Bence, A. E., 1980. Mineral chemistry of basalts from Ojin, Nintoku, and Suiko Seamounts, Leg 55 DSDP In Jackson, E. D., Koizumi, I., et al., Init. Repts. DSDP, 55: Washington (U.S. Govt. Printing Office), 607-638.

Coombs, D. S., 1963. Trends and affinities of basaltic magmas and pyroxenes as illustrated on the diopside-olivine-silica diagram. Spec. Pap. Mineral. Soc. Am., 1:227-250.

Dunham, A. C., and Wilkinson, F. C. F., 1978. Accuracy, precision and detection limits of energy-dispersive electron microprobe analysis of silicates. X-Ray Spectrom., 7:50-56.

Humphris, S. E., Melson, W. G., and Thompson, R. N., 1980. Basalt weathering on the East Pacific Rise and the Galapagos Spreading Center, Deep Sea Drilling Project, Leg 54. In Rosendahl, B. R., Hekinian, et al., Init. Repts. DSDP, 54: Washington (U.S. Govt. Printing Office), 773-787.

Humphris, S. E., Thompson, R. N., and Marriner, G. F., 1980. The mineralogy and geochemistry of basalt weathering, Holes $417 \mathrm{~A}$ and 418A. In Donnelly, T., Francheteau, J., Bryan, W., Robinson, P., Flower, M., Salisbury, M., et al., Init. Repts. DSDP, 51, 52, 53, Pt. 2: Washington (U.S. Govt. Printing Office), 1201-1218.

Kelts, K., and Arthur, M. A., 1981. Turbidites after ten years of deep sea drilling-wringing out the mop? In Warme, J. E., Douglas, R. 
G., Winterer, E. L., (Eds.), The Deep Sea Drilling Project-A Decade of Progress. Soc. Econ. Paleontol. Mineral. Spec. Publ., 32: 91-127.

Larson, R. L., and Schlanger. S. O., 1981. Geological evolution of the Nauru Basin and regional implications. In Larson, R. L., Schlanger, S. O., et al., Init. Repts. DSDP, 61: Washington (U.S. Govt. Printing Office), 841-862.

Le Bas, M. J., 1962. The role of aluminum in igneous clinopyroxenes with relation to their parentage. Am. J. Sci., 260:267-268.

Leterrier, J., Manry, R. C., Thonon, P., Girard, D., and Marchal, M., 1982. Clinopyroxene composition as a method of identification of the magmatic affinities of palaeovolcanic series. Earth Planet. Sci. Letters, 59:139-154.

Macdonald, G. A., and Katsura, T., 1964. Chemical composition of Hawaiian lavas. J. Petrol., 5:83-133.

Nisbet, E. G., and Pearce, J. A., 1977. Clinopyroxene composition in mafic lavas from different tectonic settings. Contrib. Mineral. Petrol., 63:149-160.

Pritchard, R. G., 1980. Alternation of basalts from Deep Sea Drilling Project Legs 51, 52, and 53, Holes 417A and 418A. In Donnelly, T., Francheteau, J., Bryan, W., Robinson, P., Flower, M., Salisbury, M., et al., Init. Repts. DSDP 51, 52, 53, Pt. 2: Washington (U.S. Govt. Printing Office), 1185-1200.

Pritchard, R. G., Cann, J. R., and Wood, D. A., 1979. Low-temperature alteration of ocean basalts, DSDP Leg 49. In Luyendyk, B. P., Cann, J. R., et al., Init. Repts. DSDP, 49: Washington (U.S. Govt. Printing Office), 709-714.

Robinson, P. T., Flower, M. F. J., Schminke, H.-U., and Ohnmacht, W., 1977. Low-temperature alteration of oceanic basalts, DSDP Leg 37. In Aumento, F., Melson, W. G., et al., Init. Repts. DSDP, 37: Washington (U.S. Govt. Printing Office), 775-789.

Ross, C. S., and Hendricks, S. B., 1945. Minerals of the montmorillonite group. U.S. Geol. Surv. Prof. Pap., 205-B.

Scarfe, C. M., and Smith, D. G. W., 1977. Secondary minerals in some basaltic rocks from DSDP Leg 37. Can. J. Earth Sci., 14: 903-910.
Scheidegger, K. F., and Stakes , D. S., 1977. Mineralogy, chemistry and crystallization sequence of clay minerals in altered tholeitic basalts from Peru Trench. Earth Planet. Sci. Lett., 36:413-422.

Schlanger, S. O., and Premoli Silva, I., 1981. Tectonic, volcanic and paleogeographic implications of deposited reef faunas of Late Cretaceous and Tertiary age from the Nauru Basin and the Line Islands. In Larson, R. L., Schlanger, S. O., et al., Init. Repts. DSDP, 61: Washington (U.S. Govt. Printing Office), 817-827.

Schweitzer, E. L., Papike, J. J., and Bence, A. E., 1979. Statistical analysis of clinopyroxenes from deep sea basalts. Am. Mineral., 64:501-513.

Seyfried, W. E., Shanks, W. C., and Dibble, W. E., 1978. Clay mineral formation in DSDP Leg 34 basalts. Earth Planet. Sci. Lett., 41: 265-276.

Stakes, D. S., and O'Neil, J. R., 1982. Mineralogy and stable isotope geochemistry of hydrothermally altered oceanic rocks. Earth Planet. Sci. Lett., 57:285-304.

Tokuyama, H., and Batiza, R., 1981. Chemical composition of igneous rocks and origin of the sill and pillow basalt complex of Nauru Basin, southwest Pacific. In Larson, R. L., Schlanger, S. O., et al., Init. Repts. DSDP, 61: Washington (U.S. Govt. Printing Office), 673-688.

Weaver, C. E., and Pollard, L. D., 1975. The chemistry of clay minerals. Developments in Sedimentology, 15: Amsterdam (Elsevier).

Wilkinson, J. F. G., 1956. Clinopyroxenes of alkaline-basalt magma. Am. Mineral., 41:724-743.

Winterer, E. L., 1973. Regional problems. In Winterer, E. L., Ewing, J. I., et al., Init. Repts. DSDP, 17: Washington (U.S. Govt. Printing Office), 911-922.

Date of Initial Receipt: 22 May 1984 Date of Acceptance: 19 October 1984 